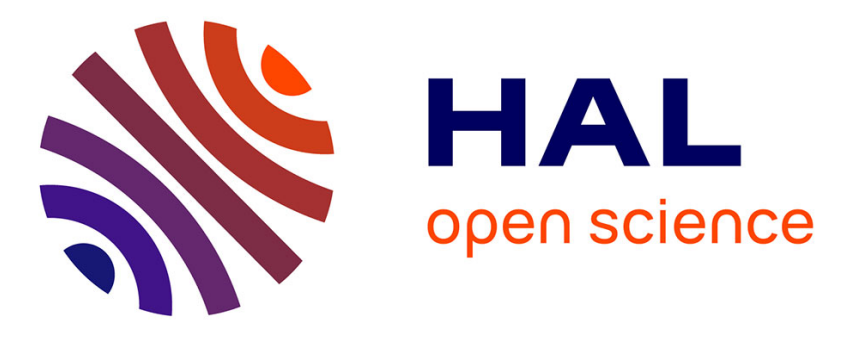

\title{
MicroRNAs related to cholesterol metabolism affected by vegetable diet in rainbow trout (Oncorhynchus mykiss) from control and selected lines
}

Tengfei Zhu, Geneviève Corraze, Elisabeth Plagnes-Juan, Jérôme Montfort, Julien Bobe, Edwige Quillet, Mathilde Dupont-Nivet, Sandrine Skiba-Cassy

\section{To cite this version:}

Tengfei Zhu, Geneviève Corraze, Elisabeth Plagnes-Juan, Jérôme Montfort, Julien Bobe, et al.. MicroRNAs related to cholesterol metabolism affected by vegetable diet in rainbow trout (Oncorhynchus mykiss) from control and selected lines. Aquaculture, 2019, 498, pp.132-142. 10.1016/j.aquaculture.2018.08.058 . hal-01870570

\author{
HAL Id: hal-01870570 \\ https://hal.science/hal-01870570
}

Submitted on 26 Nov 2018

HAL is a multi-disciplinary open access archive for the deposit and dissemination of scientific research documents, whether they are published or not. The documents may come from teaching and research institutions in France or abroad, or from public or private research centers.
L'archive ouverte pluridisciplinaire HAL, est destinée au dépôt et à la diffusion de documents scientifiques de niveau recherche, publiés ou non, émanant des établissements d'enseignement et de recherche français ou étrangers, des laboratoires publics ou privés.

\section{(c)(1)}

Distributed under a Creative Commons Attribution| 4.0 International License 


\title{
MicroRNAs related to cholesterol metabolism affected by vegetable diet in rainbow trout (Oncorhynchus mykiss) from control and selected lines
}

\author{
Tengfei Zhu ${ }^{\mathrm{a}}$, Geneviève Corraze ${ }^{\mathrm{a}}$, Elisabeth Plagnes-Juan ${ }^{\mathrm{a}}$, Jérome Montfort ${ }^{\mathrm{b}}$, Julien Bobe ${ }^{\mathrm{b}}$, Edwige Quillet $^{\mathrm{c}}$, \\ Mathilde Dupont-Nivet ${ }^{\mathrm{c}}$, Sandrine Skiba-Cassy ${ }^{\mathrm{a}, *}$ \\ a INRA, Univ Pau \& Pays Adour, E2S UPPA, UMR 1419, Nutrition Métabolisme Aquaculture, Saint Pée sur Nivelle F-64310, France \\ ${ }^{\mathrm{b}}$ UMR1313 GABI, INRA, AgroParisTech, Université Paris-Saclay, F-78350 Jouy-en-Josas, France \\ ' UR1037 LPGP, INRA, F-35000 Rennes, France
}

\begin{abstract}
For the sustainable development of aquaculture, vegetable ingredients have been used to replace the traditional ingredients fishmeal and fish oil in aquafeeds. On the other hand, selective breeding has also been implemented at research level to obtain strains that are adapted to feeding on the plant-based diet. To better understand the underlying mechanisms prompting the adaptation to plant-based diets in fish, we investigated the hepatic expression of several microRNAs (miRNAs) that are involved in the post-transcriptional regulation of cholesterol and lipid metabolism at $8 \mathrm{~h}$ and $16 \mathrm{~h}$ after the last meal in two lines of rainbow trout: one selected for better adaptation to plant-based diets and the corresponding control line. Both groups were fed either a fishmeal and fish oil based diet or a $100 \%$ plant-based diet. Results showed that the expression of miR-33a in liver was greatly elevated in trout fed the plant-based diet, while the expression of miR-122 and miR-128 was much higher in the selected line at $8 \mathrm{~h}$ after the last meal regardless of the diet. Furthermore, our results indicated that some genes involved in immune processes (caspase 6 apoptosis-related cysteine peptidase like 2, casp612) and cAMP signal transduction (phosphodiesterase 4B cAMP-specific a, pde4ba) were also potentially regulated by miRNAs. They were newly identified as putative direct targets of miRNAs and affected in trout fed the plant-based diet. Though further investigations are still needed to establish a valid relationship between miRNAs and their target genes, our study found miR-33a, miR-122 and miR-128 as potential candidates for further study and provided new perspectives to understand the role of miRNAs in the selective breeding for adaptation to the plant-based diets.
\end{abstract}

\section{Introduction}

Increasing demand for world fisheries production has resulted in a great expansion of aquaculture over the last decades, accounting for about half of the world global seafood production (FAO, 2016). As capture fisheries are limited and showed no increase since the mid1980, the increasing demand for fish in the future will be inevitably supplied by aquaculture. However, the production of fishmeal and fish oil coming from wild fishery stocks and constituting important traditional ingredients in aquafeed is also going to keep stable or even decrease (Jackson, 2012). Therefore, the utilization of plant ingredients to replace fishmeal and fish oil has been considered as the best solution to support the sustainable development of aquaculture in recent years (Tacon et al., 2010) and evident progress has been made regarding the substitution of fishmeal and fish oil by plant raw materials in salmonids and marine fish (Benedito-Palos et al., 2008; Torstensen et al., 2008).
However, studies have indicated that total replacement of fishmeal and fish oil by the plant-based diets still reduced growth performances and flesh quality (Geay et al., 2011; Panserat et al., 2009). In order to further improve the use of plant food in carnivorous fish like salmonids, research efforts have been more recently focused on the selective breeding. Indeed, the selective breeding could be the alternative solution to enhance fish adaptation to the plant-based diets and has been well confirmed at a research level. For example, it has been demonstrated that survival rate and mean body weight were improved in the first generation of rainbow trout selected for the ability to adapt to a totally plant-based diet (Le Boucher et al., 2012). Moreover, in Atlantic salmon, the deposition and/or retention of dietary n-3 long-chain polyunsaturated fatty acids (LC-PUFA) in flesh, such as eicosapentaenoic acid (EPA) and docosahexaenoic acid (DHA), is a highly heritable trait (Leaver et al., 2011) and Nofima has also carried out profitable work in this respect (Horn et al., 2017), prompting further interest in

\footnotetext{
* Corresponding author.

E-mail address: sandrine.skiba@inra.fr (S. Skiba-Cassy).
} 
exploring genotype-nutrient interactions.

The replacement of fishmeal and fish oil by plant ingredients caused great variations in nutrient supply, including the reduction of cholesterol and n-3 LC-PUFA. Cholesterol is derived from the animal organisms, so it is absent in plant ingredients (Tocher et al., 2008). In animals, cholesterol represents an important component of the membrane to modulate the fluidity and permeability and it is also the precursor of many biologically active compounds, including bile acids, steroid hormones and vitamin D (Goedeke and Fernández-Hernando, 2012).

To maintain cholesterol homeostasis, the expression of genes related to cholesterol metabolism is tightly controlled at both transcriptional and post-transcriptional level. The sterol regulatory element-binding proteins (SREBPs) and the liver X receptors (LXRs) are known to be well involved in the transcriptional regulation of cholesterol metabolism by targeting genes involved in the cholesterol synthesis ( $\mathrm{hmgcr}$, 3-hydroxy3-methylglutaryl-CoA, reductase) and efflux (abca1, ATP-binding-cassette transporter-A1, $a b c g 5$ and $a b c g 8$, ATP-binding-cassette transporter G5 and G8 and cyp7a1, cytochrome P450 cholesterol 7a-hydroxylase), respectively (Sakakura et al., 2001; Zhao and Dahlman-Wright, 2010). At the post-transcriptional level, a class of small non-protein coding RNAs of 19-24 nucleotides, designated as microRNA (miRNA), has been found to regulate gene expression either by mRNA decay or translational repression (Iwakawa and Tomari, 2015). Among the wide numbers of miRNAs, miR-1 (Zhong et al., 2013), miR-33a (Gerin et al., 2010; Najafi-Shoushtari et al., 2010), miR-122 (Esau et al., 2006), miR128 (Adlakha et al., 2013) and miR-223 (Vickers et al., 2014; Wang et al., 2013) were reported to be involved in the regulation of cholesterol and lipid metabolism in mammals.

The ability to grow on the plant-based diet has been proved to be genetically variable in fish (Le Boucher et al., 2011; Quinton et al., 2007). Although the growth potential has been effectively enhanced by selective breeding, the molecular mechanisms underlying this selection still remain unknown. In the present study, we used two lines of rainbow trout, the selected line which had better adaptation to the plant-based diet and the non-selected control line in order to investigate the potential role of miRNA, such as miR-1, miR-33a, miR-122, miR128 and miR-223, in the adaptation to the plant-based diet. Therefore, the hepatic expression of these miRNAs and the genes related to cholesterol metabolism were analyzed. Furthermore, as miR-33a, miR-128 and miR-223 were found to be affected by the plant-based diet or selective breeding, we expanded our study to some genes that were identified in silico as potential direct targets of these miRNAs based on the complementarity between the seed sequence of the miRNAs and the $3^{\prime}$ untranslated region (UTR) region of the rainbow trout transcripts.

\section{Materials and methods}

\subsection{Ethics statement}

Experimentation was conducted in the INRA experimental facilities (Peima facilities, Sizun, France and UMR Numéa, St-Pée-sur-Nivelle, France) authorized for animal experimentation by the French veterinary service which is the competent authority (B 29-277-02 and A 64-495-1). The experiments were in strict accordance with EU legal frameworks related to the protection of animals used for scientific research (Directive 2010/63/EU) and according to the National Guidelines for Animal Care of the French Ministry of Research (decree $\mathrm{n}^{\circ}$ 2013-118, February 1st, 2013). The scientists in charge of the experimentation received training and personal authorization $\left(\mathrm{N}^{\circ}\right.$ B64 10,003 and A29 102). In agreement with ethical committees "Comité d'Ethique Aquitaine Poissons Oiseaux" (C2EA-73) and "Comité d'Ethique Finistérien en Expérimentation Animale" (C2EA-74), the experiment reported here does not need approval by a specific ethical committee since it implies only classical rearing practices with all diets used in the experiment formulated to cover the nutritional requirements of rainbow trout (National Research Council, 2011). Fish were monitored daily during the experiment. If any clinical symptoms (i.e. morphological abnormality, restlessness or uncoordinated movements) were observed, fish were sedated by immersion in $2 \%$ benzocaine solution and then euthanized by immersion in a $6 \%$ benzocaine solution (anesthetic overdose) during $3 \mathrm{~min}$.

\subsection{Fish, diet and experimental design}

The experiment was conducted on two groups of rainbow trout: one line (S) which has been selected for better ability to grow and survive with a totally plant-based diet for three generations (Callet et al., 2017; Le Boucher et al., 2012) and a control line (C) maintained with high effective size and without artificial selection. 3600 eggs from $S$ line and 3600 eggs from $C$ line were obtained by within line mating (18 dams and 31 sires for each line). At 19 days post fertilization (dpf), the eyed eggs were randomly distributed into 12 tanks $\left(0.25 \mathrm{~m}^{3}\right)$ with 600 eyed eggs in each tank. The fish were reared in the 12 flow-through tanks (three tanks per treatment) in INRA experimental facilities (PEIMA, Sizun, France) at $11{ }^{\circ} \mathrm{C}$ and under artificial photoperiod condition (from $8 \mathrm{am}$ to $8 \mathrm{pm}$ ). From the first-feeding stage, $\mathrm{S}$ and $\mathrm{C}$ fish were fed ad libitum with either a plant-based diet totally devoid of marine products (V diet) or a diet containing fishmeal and fish oil (M diet) during six months. Diets were manufactured in our experimental facilities of Donzacq (France) using a twin-screw extruder (Clextral, France). The M diet contained fishmeal and fish oil as main protein and lipid source, respectively. The $\mathrm{V}$ diet was formulated with a blend of vegetable oils (palm, rapeseed and linseed oils) and a blend of plant protein sources (corn and wheat gluten, soybean meal, soy protein concentrate, light white lupin, dehulled pea and extruded whole wheat). Diets were formulated to fulfill the requirements of rainbow trout according to NRC recommendations (National Research Council, 2011). Synthetic L-lysine, L-arginine, dicalcium-phosphate and soy-lecithin were added to the $\mathrm{V}$ diet to correct the deficiency in essential amino acids, phosphorous and phospholipid supply. Diet formulations and compositions are described in Table 1.

\subsection{Sampling procedure}

At the end of the feeding trial, fish were anesthetized with benzocaine $(30 \mathrm{mg} / \mathrm{L})$ and killed by a sharp blow to the head. Six fish were sampled from each tank at $8 \mathrm{~h}$ and $16 \mathrm{~h}$ after the last meal, respectively. Blood was removed from the caudal vein into EDTA syringes and centrifuged ( $1000 \mathrm{~g}, 10-15 \mathrm{~min}$ ); then recovered plasma was immediately frozen in liquid nitrogen and kept at $-80^{\circ} \mathrm{C}$ for the measurement of cholesterol and triglycerides. Liver was dissected and weighed for hepato-somatic index determination and then immediately frozen in liquid nitrogen and kept at $-80^{\circ} \mathrm{C}$. About $100 \mathrm{mg}$ was cut from the whole liver for RNA extraction and then subsequent gene and miRNA expression analyses.

\subsection{Diet and whole body composition analysis}

Proximate analysis of the experimental diets was determined according to Association of Official Analytical Chemists (AOAC, 2000) as follows: dry matter was analyzed by drying the samples to constant weight at $105^{\circ} \mathrm{C}$ for $24 \mathrm{~h}$. Crude protein was determined using the Kjeldahl method after acid digestion and estimated by multiplying nitrogen by 6.25 . Crude lipid was quantified by petroleum diethyl ether extraction using Soxhlet method. Gross energy content was determined in an adiabatic bomb calorimeter (IKA). Ash was examined by combustion in a muffle furnace at $550{ }^{\circ} \mathrm{C}$ for $16 \mathrm{~h}$. Dietary sterols were assayed on a total lipid extract by means of the Liebermann-Burchard method (Stadtman, 1957). 
Table 1

Ingredients and proximate composition of the diets.

\begin{tabular}{|c|c|c|}
\hline Ingredients (\%) & M & $\mathrm{V}$ \\
\hline Fish meal & 58.42 & 0.00 \\
\hline Corn gluten & 0.00 & 16.03 \\
\hline Wheat gluten & 0.00 & 17.72 \\
\hline Soybean meal & 0.00 & 10.13 \\
\hline Soy protein concentrate & 0.00 & 15.19 \\
\hline Light white lupin & 0.00 & 6.75 \\
\hline Dehulled pea & 0.00 & 4.30 \\
\hline Extruded whole wheat, & 25.26 & 3.38 \\
\hline Fish oil & 14.09 & 0.00 \\
\hline Vegetable oils ${ }^{\mathrm{a}}$ & 0.00 & 15.61 \\
\hline Mineral premix ${ }^{b}$ & 1.12 & 1.18 \\
\hline Vitamin premix ${ }^{c}$ & 1.12 & 1.18 \\
\hline Soy lecithin & 0.00 & 2.11 \\
\hline L-lysine & 0.00 & 1.52 \\
\hline L-methionine & 0.00 & 0.34 \\
\hline СaHPO4.2H2O & 0.00 & 3.21 \\
\hline Attractant Mix & 0.00 & 1.35 \\
\hline \multicolumn{3}{|l|}{ Analytical composition } \\
\hline Dry Matter (DM, \%) & 90.13 & 94.41 \\
\hline Crude protein (\% DM) & 46.98 & 50.01 \\
\hline Lipid (\% DM) & 18.80 & 19.49 \\
\hline Sterols (\% DM) & 0.77 & 0.35 \\
\hline Energy (kJ/g DM) & 23.24 & 23.84 \\
\hline Ash (\% DM) & 8.17 & 6.25 \\
\hline
\end{tabular}

a Vegetable oils: palm oil (30\%), rapeseed oil (55\%), linseed oil (15\%).

b Mineral premix (g or $\mathrm{mg} / \mathrm{kg}$ diet): calcium carbonate (40\% Ca), $2.15 \mathrm{~g}$; magnesium oxide $(60 \% \mathrm{Mg}), 1.24 \mathrm{~g}$; ferric citrate, $0.2 \mathrm{~g}$; potassium iodide $(75 \%$ I), $0.4 \mathrm{mg}$; zinc sulfate $(36 \% \mathrm{Zn}), 0.4 \mathrm{~g}$; copper sulfate $(25 \% \mathrm{Cu}), 0.3 \mathrm{~g}$; manganese sulfate $(33 \% \mathrm{Mn}), 0.3 \mathrm{~g}$; dibasic calcium phosphate $(20 \% \mathrm{Ca}, 18 \% \mathrm{P})$, $5 \mathrm{~g}$; cobalt sulfate, $2 \mathrm{mg}$; sodium selenite ( $30 \% \mathrm{Se}$ ), $3 \mathrm{mg} ; \mathrm{KCl}, 0.9 \mathrm{~g}$; and $\mathrm{NaCl}$, $0.4 \mathrm{~g}$ (UPAE, INRA).

c Vitamin premix (IU or $\mathrm{mg} / \mathrm{kg}$ diet): DL- $\alpha$-tocopherol acetate, $60 \mathrm{IU}$; sodium menadione bisulphate, $5 \mathrm{mg}$; retinyl acetate, 15,000 IU; DL-cholecalciferol, $3000 \mathrm{IU}$; thiamin, $15 \mathrm{mg}$; riboflavin, $30 \mathrm{mg}$; pyridoxine, $15 \mathrm{mg}$; B12, $0.05 \mathrm{mg}$; nicotinic acid, $175 \mathrm{mg}$; folic acid, $500 \mathrm{mg}$; inositol, $1000 \mathrm{mg}$; biotin, $2.5 \mathrm{mg}$; calcium panthotenate, $50 \mathrm{mg}$; and choline chloride, $2000 \mathrm{mg}$ (UPAE, INRA).

\subsection{Analysis of plasma metabolites}

Plasma metabolite concentration was measured using commercial kits, triglycerides (PAP 150, bioMérieux, France) and cholesterol (CHOD-PAP, Sobioda, France), adapted to microplate format, according to the recommendations of the manufacturer.

\subsection{In silico identification of miRNA target gene}

Putative miRNA targets were predicted using the miRanda algorithm (www.ncbi.nlm.nih.gov/pubmed/15502875) applied to studied mature miRNA sequences and rainbow trout 3'UTR regions. Rainbow trout 3'UTR regions were predicted using a set of 78,415 contigs originating from de novo assembled RNA-seq data publicly available in the PhyloFish online database (www.ncbi.nlm.nih.gov/pubmed/27189481). In order to focus on the 3'UTR of the contigs, zebrafish reference proteins obtained from ensembl (www.ensembl.org) were blasted onto the rainbow trout PhyloFish contigs. The region dowstream of the alignment region on each contig was subsequently kept for further analysis using miRanda with default parameters.

\subsection{Gene expression analysis}

Quantitative RT-PCR gene expression analyses were performed on liver samples $(n=6)$ collected $8 \mathrm{~h}$ and $16 \mathrm{~h}$ after the last meal. Genes analyzed in the present study were: HMG-CoA reductase ( $h m g c r)$, HMGCoA synthase (hmgcs), lanosterol 14 $\alpha$-demethylase (cyp51) and 7-dehydrocholesterol reductase ( $d h c r 7$ ) for cholesterol biosynthesis, ATPbinding cassette transporter G5 (abcg5) and ATP-binding cassette transporter G8 (abcg8) for cholesterol excretion, cholesterol $7 \alpha$-hydroxylase (cyp7a1) for bile acid synthesis, ATP-binding cassette transporter A1 (abca1) for plasma cholesterol efflux, sterol regulatory elementbinding protein 2 (srebp-2) and liver $\mathrm{X}$ receptor $\alpha$ (lxr $\alpha)$ as transcriptional factors, acyl-CoA cholesterol acyltransferase 1 (acat1) and acylCoA cholesterol acyltransferase 2 (acat2) for cholesterol esterification, fatty acid synthase (fas) and the transcription factor sterol regulatory element-binding protein 1c (srebp-1c) for lipogenesis and glucokinase (gck) for glycolysis although known as the first step of lipogenesis. Analysis was also expanded to genes identified as potential direct targets of miRNAs, including the genes targeted by miR-33a (retinol dehydrogenase 14a ( $r d h 14 a)$, caspase 6 apoptosis-related cysteine peptidase like 2 (casp6l2), leucine carboxyl methyltransferase 2 (lcmt2)), the genes targeted by miR-122 (cytochrome P450 family 27 subfamily A polypeptide 7 (cyp27a7), methyltransferase like 5 (mettl5), histone deacetylase 3 ( $h d a c 3$ ), hypoxia-inducible factor 1 a subunit a (hif1aa)), and the genes targeted by miR-128 (phosphodiesterase 4B cAMP-specific a (pde4ba) and RAR-related orphan receptor A paralog a (roraa)). Total RNA was extracted as previously described (Mennigen et al., 2013) using the Trizol reagent (Invitrogen, Carlsbad, CA, USA) according to the manufacturer's instructions and was quantified by spectrophotometry (absorbance at $260 \mathrm{~nm}$ ). The integrity of the samples was assessed using agarose gel electrophoresis. $1 \mu \mathrm{g}$ of total RNA was used for cDNA synthesis. The SuperScript III RNaseH-reverse transcriptase kit (Invitrogen) with oligo dT random primers (Promega, Charbonniéres, France) was used to synthesize cDNA ( $n=6$ for cholesterol metabolism genes in $6 \mathrm{~h}$ ). The primer sequences used for qRTPCR analyses are listed in the Table 4 and Table 5. Quantitative RT-PCR assays were performed on the Roche LightCycler 480 II system (Roche Diagnostics, Neuilly sur Seine, France). The assays were carried out using a reaction mix of $6 \mu \mathrm{L}$ per sample containing $2 \mu \mathrm{L}$ of 76 times diluted cDNA, $0.24 \mu \mathrm{L}$ of each primer $(10 \mu \mathrm{M}), 3 \mu \mathrm{L}$ of LightCycler 480 SYBR $^{\circledast}$ Green I Master mix and $0.52 \mu \mathrm{L}$ DNAse/RNAse free water (5 Prime GmbH, Hamburg, Germany). The PCR protocol was initiated at $95^{\circ} \mathrm{C}$ for $10 \mathrm{~min}$ for initial denaturation of the cDNA and hot-start Taqpolymerase activation, followed by 45 cycles of a three-step amplification program $\left(15 \mathrm{~s}\right.$ at $95^{\circ} \mathrm{C}, 10 \mathrm{~s}$ at melting temperature $\mathrm{Tm}$ $\left(60-65^{\circ} \mathrm{C}\right), 15 \mathrm{~s}$ at $\left.72{ }^{\circ} \mathrm{C}\right)$, according to the primer set used. Melting curves were systematically monitored $\left(5 \mathrm{~s}\right.$ at $95^{\circ} \mathrm{C}, 1 \mathrm{~min}$ at $65^{\circ} \mathrm{C}$, temperature gradient at $0.11^{\circ} \mathrm{C} / \mathrm{s}$ from 65 to $97^{\circ} \mathrm{C}$ ) at the end of the last amplification cycle to confirm the specificity of the amplification reaction. Each PCR assay included replicate samples (duplicate of reverse transcription and PCR amplification) and negative controls (RT- and cDNA-free samples, respectively). As the expression of $18 \mathrm{~s}$ was not significantly different among treatments at $8 \mathrm{~h}$ (data not shown) and the expression of ef $1 \alpha$ was not significantly different among treatments at $16 \mathrm{~h}$ (data not shown), the $18 \mathrm{~S}$ ribosomal RNA (18s) and elongation factor $1 \alpha(e f 1 \alpha)$ was used for the normalization of the genes at $8 \mathrm{~h}$ and $16 \mathrm{~h}$, respectively. Relative quantification of target gene expression was determined using the $E$-Method from the LightCycler 480 software (version SW 1.5; Roche Diagnostics). In all cases, PCR efficiency (E) measured by the slope of a standard curve with serial dilutions of cDNA ranged between 1.8 and 2 .

\section{8. miRNA expression analysis}

Several miRNAs including miR-1-3p, miR-33a-5p, miR-122-5p, miR128-3p and miR-223-3p were detected by the TaqMan ${ }^{\circledR}$ Advanced miRNA Assays (A25576, Applied Biosystems, ThermoFisher) in liver collected $8 \mathrm{~h}$ and $16 \mathrm{~h}$ after the last meal. The spike miR-39 (Caenorhabditis. elegans) was used as an exogenous control for normalization as previously described (Tay et al., 2017) and has been shown to be present at relatively constant levels among the four treatments. Total RNA in liver was obtained in the same way as that for gene expression analysis. 80 ng RNA were used for the poly(A) tailing, ligation and reverse transcription reactions to synthesize the cDNA of 
all miRNAs followed by a miR-Amp reaction for cDNA pre-amplification according to the manufacturer's instruction. PCR was performed in a reaction mix of $6 \mu \mathrm{L}$ containing $2 \mu \mathrm{L}$ cDNA (200 times diluted for liver cDNA and 50 times diluted for plasma cDNA), $2.67 \mu \mathrm{L} 2 \times$ Fast Advanced Master mix (Applied Biosystems, Foster city, California, USA), $0.27 \mu \mathrm{L}$ TaqMan ${ }^{\circledast}$ Advanced miRNA Assay $(20 \times$ ) (Applied Biosystems, Foster city, California, USA) and $1.06 \mu \mathrm{L}$ DNAse/RNAse free water (5 Prime GmbH, Hamburg, Germany). The sequences of the probes were listed in the Table 3. The PCR protocol was initiated at $95^{\circ} \mathrm{C}$ for 20 s for initial denaturation of the cDNA and the enzyme activation, followed by 50 cycles of a 2 steps amplification program $\left(3 \mathrm{~s}\right.$ at $95^{\circ} \mathrm{C}$ for denaturation, 30s at $60{ }^{\circ} \mathrm{C}$ for annealing). Each PCR assay included replicates for each sample (duplicates of reverse transcription and PCR amplification) and negative controls (reverse transcriptase free and RNA free samples). Relative quantification of the target miRNA was determined using the E-Method from the LightCycler 480 software (version SW 1.5; Roche Diagnostics). PCR efficiency measured by the slope of a standard curve with serial dilutions of miRNA cDNA ranged between 1.8 and 2 .

\subsection{Statistical analysis}

Results are expressed as means \pm SD. Statistical analyses were carried out using two-way ANOVA (line, diet effects and line*diet interaction), followed by a Tukey test for post hoc analysis. Normality was assessed using the Shapiro-Wilk test, while homogeneity of variance was determined using Levene's test. For all statistical analysis, the level of significance was set at $P<.05$. Statistical analysis was performed using R software (Fox and Bouchet-Valat, 2016).

\section{Results}

\subsection{Body weight, hepatosomatic index, cholesterol and triglyceride in plasma}

After 6 months of feeding, the final body weight of rainbow trout fed the $M$ diet was significantly higher than that fed the $V$ diet. As expected, the fish from the $\mathrm{S}$ line reached a higher body weight than those in the $\mathrm{C}$ group regardless the dietary treatment. However, as already shown by Le Boucher et al. (2012) and Callet et al. (2017), the selection response was significantly higher when fish were fed the $\mathrm{V}$ diet than those fed the $\mathrm{M}$ diet. This means that when we selected fish fed $100 \% \mathrm{~V}$ diet for better survival and growth, two kinds of response occurred: 1) general selection for growth which will be expressed whatever the diet, 2) specific selection linked to the V diet. The hepatosomatic index was significantly higher in trout fed the M diet and was not affected by the lines (Table 2).

The cholesterol level in plasma was higher in trout fed the $M$ diet at both $8 \mathrm{~h}$ and $16 \mathrm{~h}$ after the last meal. It was significantly affected by the line at $16 \mathrm{~h}$ after the last meal, with a significantly lower concentration of cholesterol in the plasma in the $S$ line regardless of the diet. The level
Table 3

Sequences of the probes in TaqMan ${ }^{\circledR}$ Advanced miRNA Assays.

\begin{tabular}{lll}
\hline Assay & Assay ID & Probe sequences \\
\hline miR-1-3p & 477820 mir & TGGAATGTAAAGAAGTATGTAT \\
miR-33a-5p & 478347 mir & GTGCATTGTAGTTGCATTGCA \\
miR-39-3p & 478293 mir & TCACCGGGTGTAAATCAGCTTG \\
miR-122-5p & 477855 mir & TGGAGTGTGACAATGGTGTTTG \\
miR-128-3p & 477892 mir & TCACAGTGAACCGGTCTCTTT \\
miR-223-3p & 477983 mir & TGTCAGTTTGTCAAATACCCCA \\
miR-451a & 478107 mir & AAACCGTTACCATTACTGAGTT \\
\hline
\end{tabular}

of triglycerides in plasma was higher in trout fed the $M$ diet than those fed the $\mathrm{V}$ diet but only at $16 \mathrm{~h}$ after the meal. No significant line effect was found for plasma triglycerides (Table 2).

\subsection{Hepatic expression of miRNAs}

Expression of miR-1-3p, miR-33a-5p, miR-122-5p, miR-128-3p and miR-223-3p was assessed in liver $8 \mathrm{~h}$ and $16 \mathrm{~h}$ after the last meal (Fig. 1). The expression of miR-1 and miR-223 was not affected by diet nor by line. Interestingly, miR-33a was expressed significantly lower in the liver of fish fed the $\mathrm{M}$ diet at both $8 \mathrm{~h}$ and $16 \mathrm{~h}$. The expression of miR-122 and miR-128 significantly increased in the $S$ line compared to the $\mathrm{C}$ line at $8 \mathrm{~h}$ after the meal. miR-122 was also found to be less expressed in fish fed the $\mathrm{V}$ diet but only at $16 \mathrm{~h}$.

\subsection{Hepatic expression of genes related to cholesterol and lipid metabolism}

We analyzed the hepatic expression of genes related to cholesterol and lipid metabolism or potentially regulated by miR-1-3p, miR-33a5p, miR-122-5p, miR-128-3p and miR-223-3p (Fig.2). With a high concordance among genes involved in cholesterol synthesis, the expression of $h m g c r, h m g c s$, cyp51 and dhcr7 significantly increased in the liver of fish fed the $\mathrm{V}$ diet at both $8 \mathrm{~h}$ and $16 \mathrm{~h}$ after the last meal. However, none of them were affected by the line. Correspondingly, the expression of their regulator srebp-2 showed the same significant variation with higher expression in fish fed the $\mathrm{V}$ diet regardless of the lines at both $8 \mathrm{~h}$ and $16 \mathrm{~h}$. The genes involved in cholesterol efflux were shown to be affected either by diet or line. The $\mathrm{V}$ diet significantly increased the expression of $a b c g 5$ at $8 \mathrm{~h}, c y p 7 a 1$ and $a b c a 1$ at both $8 \mathrm{~h}$ and $16 \mathrm{~h}$ after the meal. On the contrary, selective breeding for better adaptation to the plant-based diet leaded to decreased expression of $a b c g 8$ at $16 \mathrm{~h}$ after the meal. The only gene not affected by the treatments was lxra, which was not affected neither by diet nor line. Regarding the genes involved in cholesterol esterification, a significant interaction between diets and lines was found for acat1 which was higher expressed in the fish from the selected line fed the M diet. A significantly higher expression of acat 2 was observed in both lines fed the $\mathrm{V}$ diet at $8 \mathrm{~h}$ after the meal. Whatever the line, the expression of fas

Table 2

Morphometric parameters in rainbow trout from selected (S) line and control (C) line fed the marine (M) diet and vegetable (V) diet (C-M represents for the rainbow trout from $\mathrm{C}$ line fed the $\mathrm{M}$ diet, etc.);

\begin{tabular}{|c|c|c|c|c|c|c|c|c|c|c|c|c|}
\hline & & \multicolumn{2}{|l|}{ C-M } & \multicolumn{2}{|l|}{$\mathrm{C}-\mathrm{V}$} & \multicolumn{2}{|l|}{ S-M } & \multicolumn{2}{|l|}{ S-V } & \multicolumn{3}{|c|}{ ANOVA: $P$ values } \\
\hline BW (g) & & 42.70 & 5.61 & 30.23 & 6.99 & 54.65 & 8.33 & 40.00 & 4.46 & $0.000^{* *}$ & $0.000^{* *}$ & 0.618 \\
\hline \multicolumn{13}{|l|}{ Plasma } \\
\hline \multirow[t]{2}{*}{ Chol (g/L) } & $8 \mathrm{~h}$ & 3.57 & 0.95 & 2.17 & 0.30 & 4.03 & 0.89 & 2.13 & 0.29 & $0.000^{* *}$ & 0.456 & 0.379 \\
\hline & $16 \mathrm{~h}$ & 4.69 & 0.31 & 2.23 & 0.59 & 3.72 & 0.74 & 1.74 & 0.47 & $0.000^{* * *}$ & $0.004^{* *}$ & 0.306 \\
\hline TG (g/L) & $8 \mathrm{~h}$ & 4.06 & 0.46 & 4.36 & 1.20 & 4.30 & 0.93 & 4.18 & 1.04 & 0.809 & 0.935 & 0.595 \\
\hline
\end{tabular}

(BW: final body weight; HSI: hepatosomatic index; Chol: cholesterol; TG: triglyceride; $n=9$ for BW and HSI, $\mathrm{n}=6$ for Chol and TG, two-way analysis of variance, two stars represent a $\mathrm{P}$ value $<.01)$ 
Table 4

Primer sequences of cholesterol metabolic and lipogenic genes.

\begin{tabular}{|c|c|c|c|c|}
\hline \multirow[t]{2}{*}{ Gene } & \multirow[t]{2}{*}{ Forward primer } & \multirow[t]{2}{*}{ Reverse primer } & \multicolumn{2}{|c|}{ Genoscope $^{\mathrm{a}}$ or Genbank accession numbers } \\
\hline & & & Paralogue 1 & Paralogue 2 \\
\hline$a b c a 1$ & CAGGAAAGACGAGCACCTT & TCTGCCACСТСACACACTTC & GSONMG00078741001 & GSONMG00074045001 \\
\hline$a b c g 5$ & CACCGACATGGAGACAGAAA & GACAGATGGAAGGGGATGAA & GSONMG00075025001 & / \\
\hline abcg8 & GATACCAGGGTTCCAGAGCA & CCAGAAACAGAGGGACCAGA & GSONMG00075024001 & / \\
\hline acat1 & GGCAAGCCTGATGTGGTAGT & ACCGTGCCATTCTCCTTCTG & GSONMG00033938001 & / \\
\hline acat2 & TGCTTGTTGTCCCTGGGTTT & GTGTGGCTGTGACGTGTTTC & GSONMG00054446001 & GSONMG00054447001 \\
\hline cyp51 & CCCGTTGTCAGCTTTACCA & GCATTGAGATCTTCGTTCTTGC & GSONMG00031182001 & GSONMG00044416001 \\
\hline cyp7a1 & ACGTCCGAGTGGCTAAAGAG & GGTCAAAGTGGAGCATCTGG & AB675933.1 GSONMG00066448001 & AB675934.1 GSONMG00037174001 \\
\hline dhcr7 & GTAACCCACCAGACCCAAGA & CCTCTCCTATGCAGCCAAC & GSONMG00025402001 & GSONMG00039624001 \\
\hline fas & TGATCTGAAGGCCCGTGTCA & GGGTGACGTTGCCGTGGTAT & GSONMG00062364001 & \\
\hline gck & GCACGGCTGAGATGCTCTTTG & GCCTTGAACCCTTTGGTCCAG & GSONMG00033781001 & GSONMG00012878001 \\
\hline hmgcr & GACCATTTGGGAGCTTGTGT & GAACGGTGAATGTGCTGTGT & GSONMG00016350001 & / \\
\hline hmgcs & AGTGGCAAAGAGAGGGTGTG & TTCTGGTTGGAGACGAGGAG & GSONMG00010243001 & / \\
\hline lxra & TGCAGCAGCCGTATGTGGA & GCGGCGGGAGCTTCTTGTC & GSONMG00014026001 & GSONMG00064070001 \\
\hline srebp-1c & CATGCGCAGGTTGTTTCTT & GATGTGTTCGTGTGGGACTG & XM_021624594.1 & \\
\hline srebp-2 & TAGGCCCCAAAGGGATAAAG & TCAGACACGACGAGCACAA & GSONMG00039651001 & GSONMG00061885001 \\
\hline $18 s$ & CGGAGGTTCGAAGACGATCA & TCGCTAGTTGGCATCGTTTAT & & \\
\hline ef1 $\alpha$ & TCCTCTTGGTCGTTTCGCTG & ACCCGAGGGACATCCTGTG & AF498320.1 & / \\
\hline
\end{tabular}

a https://www.genoscope.cns.fr/trout

and srebp- $1 c$ was higher in fish fed the $\mathrm{V}$ diet at both $8 \mathrm{~h}$ and $16 \mathrm{~h}$ after the meal, however, the expression of gck was much lower in fish fed the $\mathrm{V}$ diet at $8 \mathrm{~h}$ and $16 \mathrm{~h}$. The expression of gck was also affected by the line, with much higher expression in the $S$ line at $8 \mathrm{~h}$. In summary, the expression of most genes related to cholesterol and lipid metabolism was affected by the $\mathrm{V}$ diet rather than the lines, showing a higher expression in both lines fed the $\mathrm{V}$ diet.

\subsection{Expression of target genes by corresponding miRNAs in liver}

Based on sequence complementarity between the seed sequences of miR-33a-5p, miR-122-5p and miR-128-3p and 3'UTR region of rainbow trout mRNAs, a list of potential direct targets of these previous cited miRNAs was established (Supplementary data S1-3). We analyzed the expression of $r d h 14 a$, casp $6 l 2$ and lcmt2 as potential direct targets of miR-33a (Fig. 3A). Among the three genes targeted by miR-33a, only the expression of casp6l2 was detected to be affected by diet and line. The expression of casp6l2 was significantly lower in fish fed the $\mathrm{V}$ diet at both $8 \mathrm{~h}$ and $16 \mathrm{~h}$ after the meal and significantly higher in S line only at $8 \mathrm{~h}$ after the meal. However, no significant difference was found in the expression of $r d h 14 a$ and lcmt2. Regarding the genes targeted by miR-122 (cyp27a7, mettl5, hdac3 and hif1aa) (Fig. 3B), we observed that feeding trout with the $\mathrm{V}$ diet resulted in decreased expression of cyp27a7 at $8 \mathrm{~h}$ after the meal. A significant interaction between diet and line effects was found for mettl 5 at $16 \mathrm{~h}$ after the meal, showing a higher expression in the $S$ line than the $C$ line when fish were fed the $M$ diet but a lower expression in the $\mathrm{S}$ line when fish were fed the $\mathrm{V}$ diet. On the other hand, the expression of hdac3 and hif1aa was not affected by diets or lines at both time points. We finally analyzed pde4ba and roraa as putative direct targets of miR-128 (Fig. 3C). Both genes expressed at
Table 6

Correlations between miRNAs and their potential target genes.

\begin{tabular}{llll}
\hline \multirow{2}{*}{ miRNAs } & Potential target gene & \multicolumn{2}{l}{ Pearson value } \\
\cline { 3 - 4 } & & $8 \mathrm{~h}$ & $16 \mathrm{~h}$ \\
\hline miR-33a & rdh14a & -0.31 & 0.3051 \\
& casp6l2 & $-0.47 *$ & -0.3813 \\
miR-122 & lcmt2 & -0.06 & -0.0878 \\
& cyp27a7 & $0.42_{*}$ & 0.0442 \\
& mettl5 & 0.21 & 0.3137 \\
miR-128 & hdac3 & -0.13 & 0.1321 \\
& hif1aa & 0.08 & 0.259 \\
& pde4ba & -0.25 & 0.3258 \\
& roraa & -0.09 & 0.9701 \\
\hline
\end{tabular}

Pearson correlation coefficient larger than zero is positive correlation, while Pearson correlation coefficient less than zero is negative correlation.

* $P<.05$ is statistically significant with one star.

much lower level in the fish fed the $\mathrm{V}$ diet at $8 \mathrm{~h}$ after the meal. This lowering effect of the $\mathrm{V}$ diet was maintained $16 \mathrm{~h}$ after the meal for pde $4 b a$. Finally, results showed that the expression of pde $4 b a$ at $16 \mathrm{~h}$ after the meal was also affected by the line, with a lower expression in the $S$ line.

\subsection{Correlations between miRNAs and their putative target genes}

Pearson correlation analysis showed that miR-33a negatively correlated with casp6l2 and miR-122 positively correlated with cyp27a7 significantly $8 \mathrm{~h}$ after the meal, however, other pairs of miRNAs and their target genes did not show any significant correlations (Table 6).

Table 5

Primer sequences of miRNA target genes.

\begin{tabular}{|c|c|c|c|}
\hline Gene & $\mathrm{F}$ primer & $\mathrm{R}$ primer & Accession number \\
\hline$r d h 14 a$ & TCCAGGGCCTTCTTCAAGAG & CAAAGTTTCCTGGCCACCTC & D2OM_RDH14A.2.2 \\
\hline casp6l2 & TTCGTGTGCGTCTTTCTGAG & CACTGGATCGTCATGCTTGT & D2OM_LOC100135902.1.1 \\
\hline lcmt2 & CCGACAACCCTTCACAGATT & GAGCTTTTCGTTCCCCTACC & D2OM_LCMT1.1.1 \\
\hline cyp $27 a 7$ & AGTGGTACAAGCTGCGGACT & GGACAGGTTGGTCACAAGGT & D2OM_CYP27A7.3.3 \\
\hline mettl5 & AAGTGGACGCCTTTGAAGAA & CCAACACACAAACCTGCATC & D2OM_METL5.1.1 \\
\hline hdac3 & GGCAACTCTTTCAGCCAGTC & GGGGAATCCTGAAGCTTTTC & D2OM_HDAC3.2.3 \\
\hline hif1aa & CCCAACССCTAGAGTGCTC & TGGTGAGTAAGGAAGCAGGG & D2OM_HIF1A.3.4 \\
\hline pde $4 b a$ & CAGCAATCCATGATGTGGAC & TTGGTCAGGCTCTGGAAGAT & D2OM_PDE4B.2.2 \\
\hline roraa & TCAGTGGCTACATGGACAGC & GGGATGTCTCTCCGTTGGTA & D2OM_contig_006818 \\
\hline
\end{tabular}



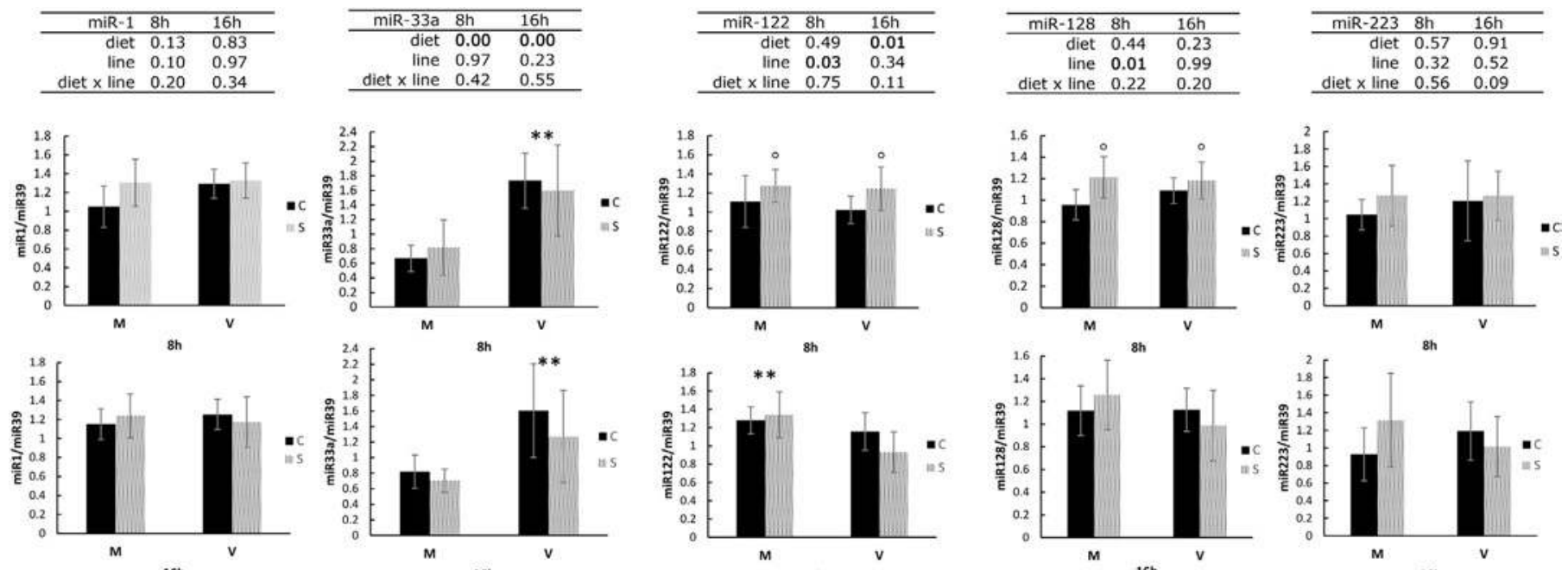

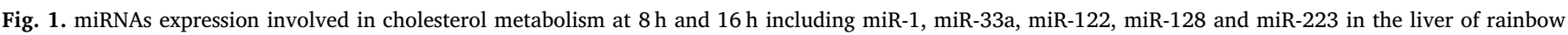

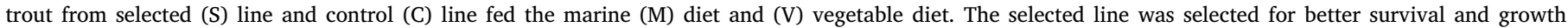

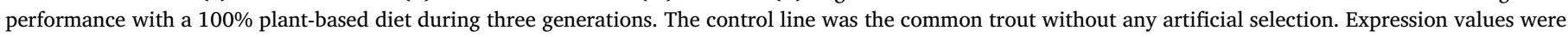

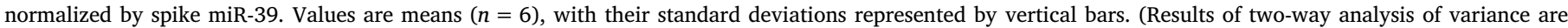

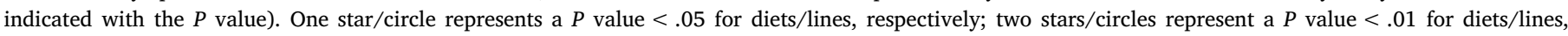
respectively.

\section{Discussion}

Selective breeding in fish for better adaptation to plant-based diet represents a promising future in aquaculture when increasingly more fishmeal and fish oil are replaced by vegetable ingredients in aquafeeds. Recent selective breeding program developed in rainbow trout has proven that individual variability in the ability to survive and grow on the plant-based diet can be effectively used to promote fish production (Le Boucher et al., 2011). In order to decipher the molecular mechanisms underlying this adaptation to the plant-based diet totally devoid of marine ingredients, we examined the expression of five miRNAs potentially involved in the regulation of lipid and cholesterol metabolism in the liver of control and selected rainbow. We also analyzed the hepatic expression of putative indirect and direct target genes of these miRNAs.

Our study demonstrated that the hepatic expression of miRNAs could be affected either in fish fed the $100 \%$ plant-based diet or in line selected for better adaptation to the plant-based diet by selective breeding. The vegetable diet increased the hepatic expression of miR33a, while selective breeding for better survival and growth on the totally plant-based diet enhanced the expression of miR-122 and miR128. However, the miR-1 (reported to inhibit lxra expression (Zhong et al., 2013), which may result in cellular cholesterol increase via reducing cholesterol efflux and conversion to bile acids) and miR-223 (known to reduce cellular cholesterol and promote cholesterol efflux by directly repressing $h m g c s$ and indirectly increasing abca1 and cyp7a1, respectively (Vickers et al., 2014)), were not modified by the diet nor the selective breeding.

One particularity of the miR-33a in human is that its gene is located in the intron of srebp-2, the gene encoding SREBP-2 protein (Marquart et al., 2010). This particularity seems to be conserved across animal species, since miR-33a is also positioned in an intron of the srebp-2 gene in rainbow trout. The concomitance and co-expression of srebp-2 and miR-33a could be the reason why the expression of both miR-33a and srebp-2 were found to be concurrently higher in trout fed the plantbased diet. In mammals, miR-33a could repress the cholesterol efflux by targeting abcg5 and abcg8 (involved in direct cholesterol discharge into the bile), cyp7a1 (key enzyme in bile acid synthesis) and abca1 (contributing to hepatic cholesterol efflux to plasma) (Bommer and MacDougald, 2011; Gerin et al., 2010; Li et al., 2013). The increasing expression of miR-33a might indicate the repression of cholesterol export and bile acid synthesis (Gerin et al., 2010; Li et al., 2013) when trout were fed the plant-based diet. However, the higher expression of cholesterol efflux genes (abca1, cyp7a1 and abcg5) found in trout fed the $\mathrm{V}$ diet in the present study goes against this hypothesis. This discrepancy may be attributed to the variety of factors acting at transcriptional or post-transcriptional levels that orchestrate the regulation of gene expression together. For example, in mammals, it was reported that srebp-2 positively regulated the expression of abca1 (Wong et al., 2006) and the unusually long 3'UTR of abca1 also harbors many binding sites of other miRNAs (Ramirez et al., 2011) that probably also contribute to the regulation of abca1. Therefore, in the present study, the higher expression of abca1 in trout fed the $\mathrm{V}$ diet may be due to the higher expression of srebp-2 and/or the involvement of other miRNAs counteracting the effect of the miR-33a.

miR-122, a liver specific miRNA, has been suggested to play roles in cholesterol and lipid metabolism (Esau et al., 2006; Krützfeldt et al., 2005). In contrast to most other miRNAs inhibiting gene expression, miR-122 works to promote the expression of genes involved in cholesterol and fatty acid synthesis through a mechanism still unknown (Aryal et al., 2017; Iliopoulos et al., 2010; Krützfeldt et al., 2005). In the present study, miR-122 expression was shown to be affected by the selective breeding with enhanced expression in the selected line compared to the control line at $8 \mathrm{~h}$ after the meal. However, the increase in miR-122 in the selected line was not associated with a concomitant enhanced expression of genes involved in cholesterol biosynthesis (hmgcr, hmgcs, cyp51 and dhcr7) or lipogenesis (fas and srebp-1c). Similarly, the promoting effect of the vegetable diet on the expression of the foregoing genes was not accompanied by an enhanced expression of miR-122. Therefore, the present study confirms our previous results that in vivo inhibition of miR-122 by antagomir in trout did not affect the expression of genes involved in cholesterol synthesis (Mennigen et al., 2014).

Similar to miR-122, the expression of miR-128 increased in the selected line regardless of the diets. This increase was only observed $8 \mathrm{~h}$ after the meal, confirming our previous investigations that miRNAs could be under postprandial nutritional control in fish (Mennigen et al., 2012). miR-128 is considered as an actor to regulate cholesterol homeostasis by limiting cholesterol efflux (Adlakha et al., 2013). Cholesterol efflux is a mechanism implemented by cells to eliminate excess 
cholesterol and prevent cellular cholesterol accumulation. This efflux is mediated by the ABCA1, of which expression has been shown to be inhibited at both mRNA and protein level by miR-128 through direct binding to the 3'UTR region of abca1 mRNA (Adlakha et al., 2013). The positive effect of the selective breeding on the expression of miR-128 seems to be consistent with the lower plasma cholesterol level measured in the selected line at $16 \mathrm{~h}$ after the meal. However, the higher expression of miR-128 but lower plasma cholesterol in selected line was inconsistent with the result of abca1 expression at mRNA level, which was not affected by selective breeding. Therefore, further investigations are still needed to determine if abca1 expression could be affected by the miR-128 at protein level rather than mRNA level.

In the present study, the expressions of miR-33a, miR-122 and miR128 in liver were all affected either by diets or lines, while miR-1 and miR-223 were not affected by either line or diet. Therefore, we further utilized the 3'UTR of these three miRNAs to identify their putative
(A)

\begin{tabular}{rll}
\hline hmgcr & $8 \mathrm{~h}$ & $16 \mathrm{~h}$ \\
\hline diet & 0.00 & 0.01 \\
line & 0.78 & 0.10 \\
diet $\mathrm{x}$ line & 0.92 & 0.34 \\
\hline
\end{tabular}

\begin{tabular}{rll}
\hline hmgcs & $8 \mathrm{~h}$ & $16 \mathrm{~h}$ \\
\hline diet & 0.00 & 0.01 \\
line & 0.16 & 0.37 \\
diet $\mathrm{x}$ line & 0.54 & 0.82 \\
\hline
\end{tabular}

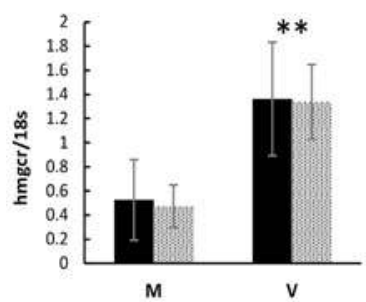

$8 h$

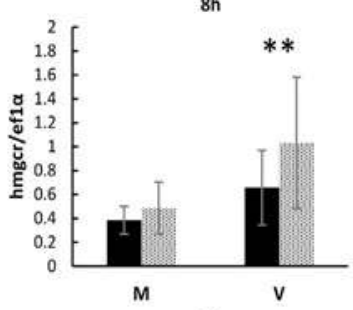

$16 \mathrm{~h}$

(B)

\begin{tabular}{rll}
\hline$a b c g 5$ & $8 \mathrm{~h}$ & $16 \mathrm{~h}$ \\
\hline diet & 0.00 & 0.36 \\
line & 0.81 & 0.75 \\
diet $x$ line & 0.58 & 0.32 \\
\hline
\end{tabular}
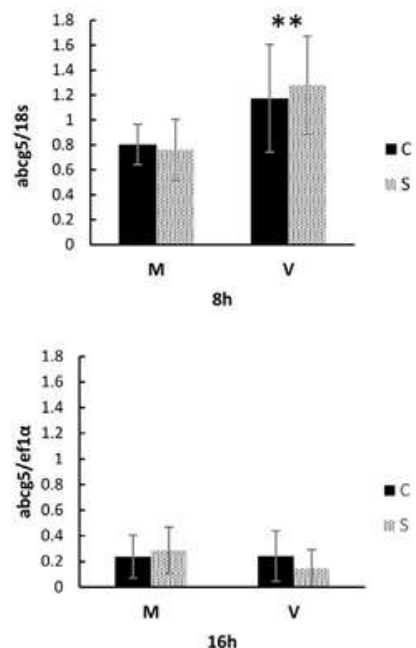

$16 \mathrm{~h}$

\begin{tabular}{rll}
\hline$a b c g 8$ & $8 \mathrm{~h}$ & $16 \mathrm{~h}$ \\
\hline diet & 0.12 & 0.59 \\
line & 0.39 & 0.03 \\
diet $\mathrm{x}$ line & 0.84 & 0.41 \\
\hline
\end{tabular}

8 h

$16 \mathrm{~h}$

\begin{tabular}{rll}
\hline cyp51 & $8 \mathrm{~h}$ & $16 \mathrm{~h}$ \\
\hline diet & 0.00 & 0.00 \\
line & 0.44 & 0.39 \\
diet $\mathrm{x}$ line & 0.61 & 0.69 \\
\hline
\end{tabular}
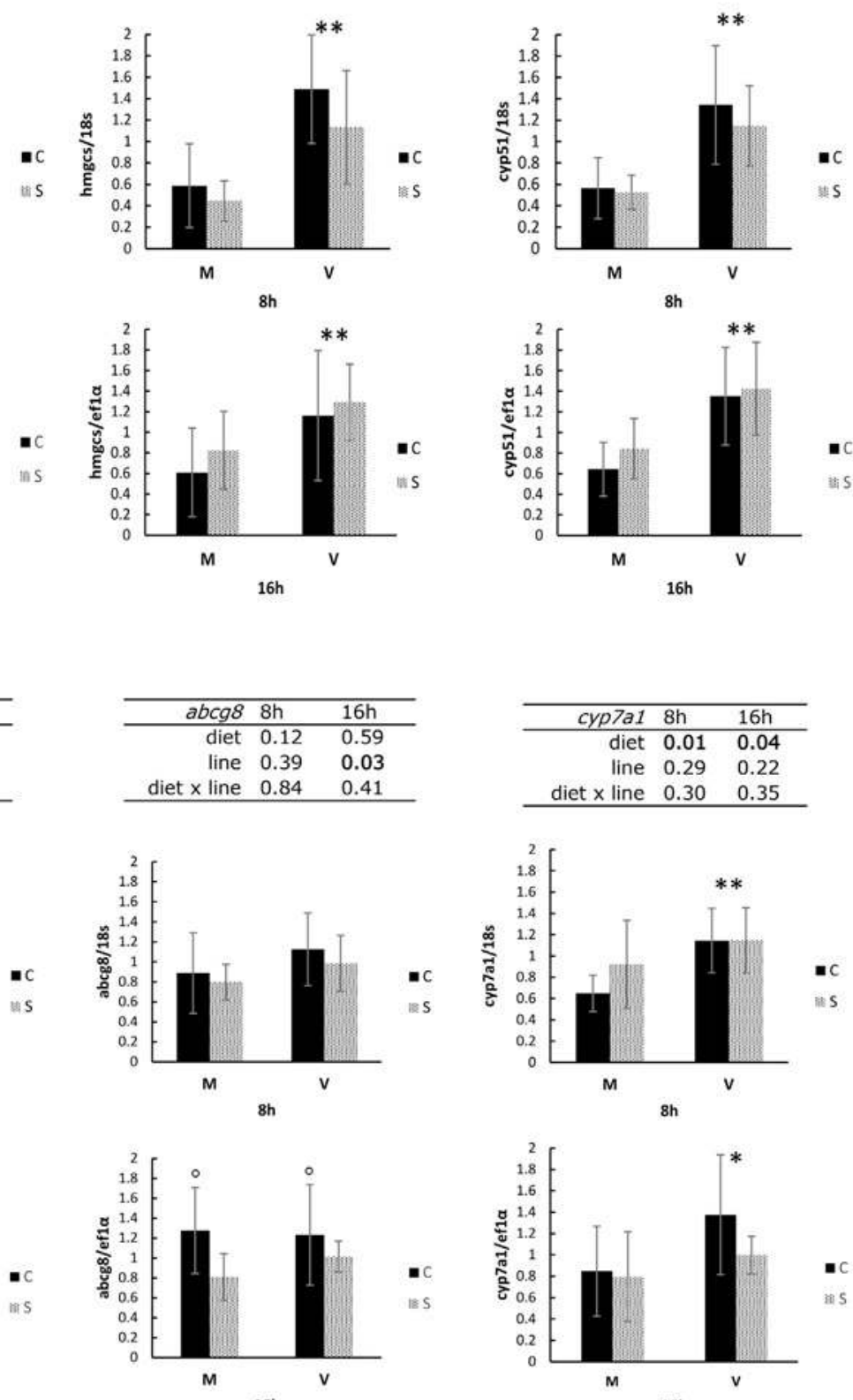

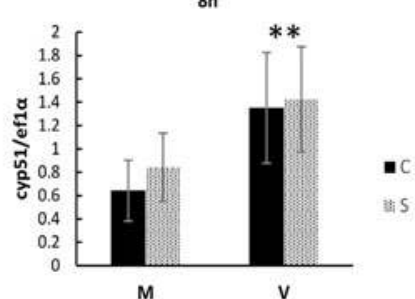

$16 \mathrm{~h}$
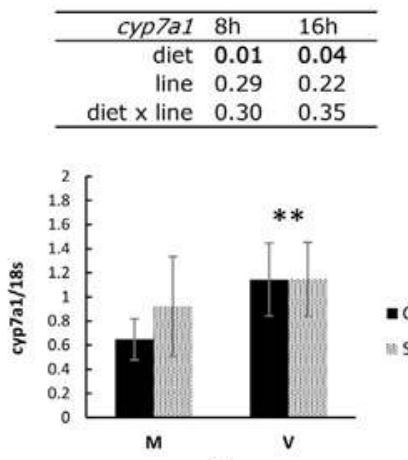

$8 \mathrm{~h}$

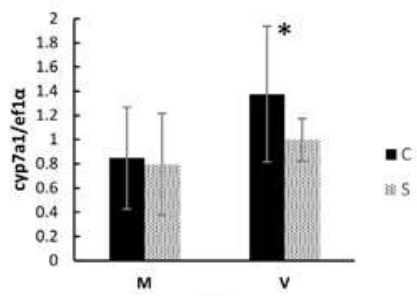

16h

\begin{tabular}{rll}
\hline dhcr 7 & $8 \mathrm{~h}$ & $16 \mathrm{~h}$ \\
\hline diet & 0.00 & 0.00 \\
line & 0.63 & 0.98 \\
diet $\mathrm{x}$ line & 0.66 & 0.64
\end{tabular}

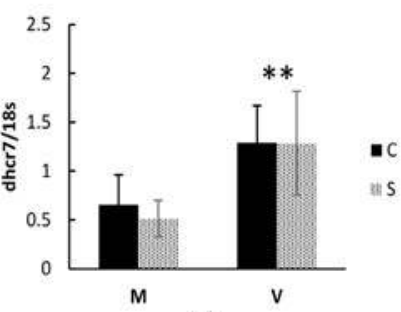

$8 \mathrm{~h}$

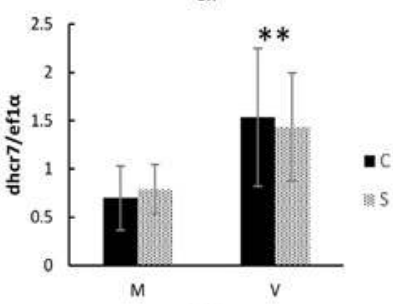

$16 \mathrm{~h}$
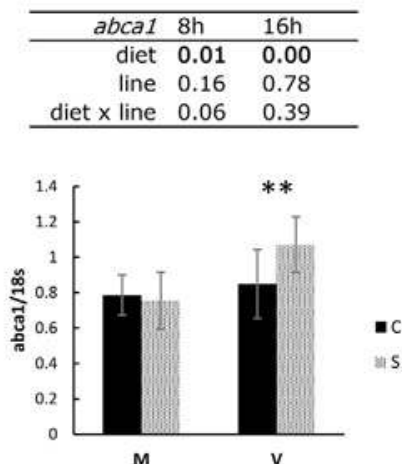

$8 \mathrm{~h}$

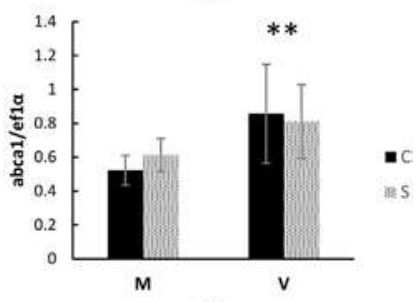

$16 \mathrm{~h}$

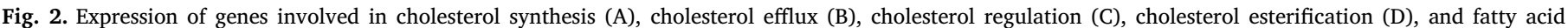

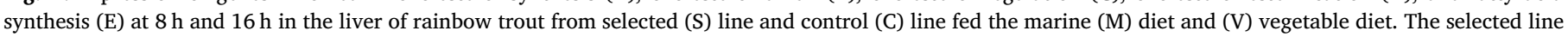

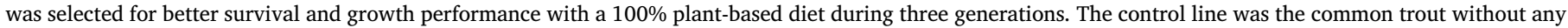

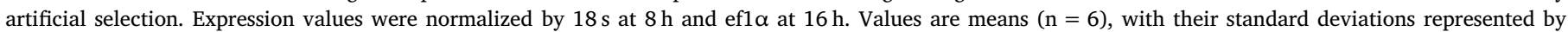

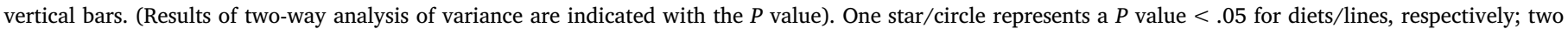
stars/circles represent a $P$ value $<.01$ for diets/lines, respectively. 


\begin{tabular}{rll}
\hline srebp-2 & $8 \mathrm{~h}$ & $16 \mathrm{~h}$ \\
\hline diet & 0.00 & 0.00 \\
line & 0.60 & 0.13 \\
diet $\mathrm{x}$ line & 0.57 & 0.96 \\
\hline
\end{tabular}

\begin{tabular}{rll}
\hline$/ x$ ra & $8 \mathrm{~h}$ & $16 \mathrm{~h}$ \\
\hline diet & 0.20 & 0.08 \\
line & 0.16 & 0.30 \\
diet $x$ line & 0.24 & 0.58 \\
\hline
\end{tabular}
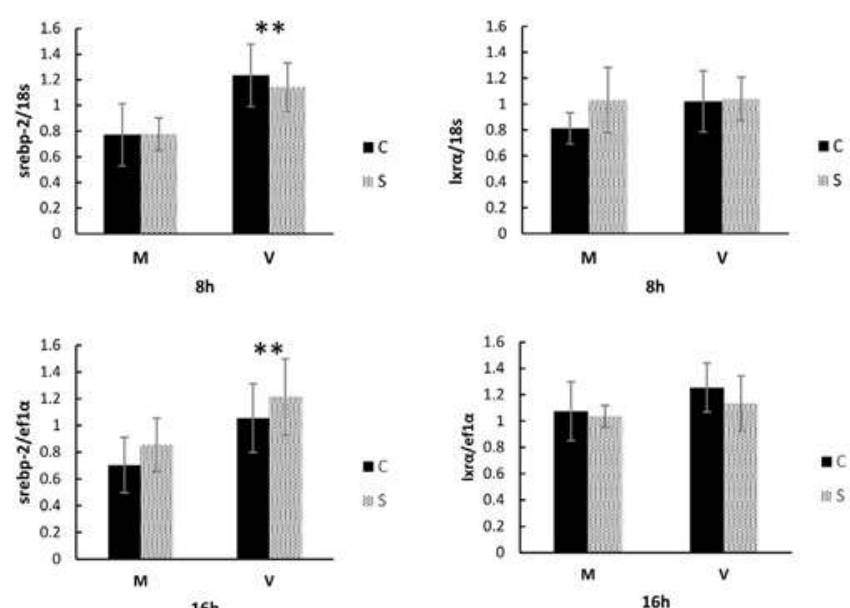

\begin{tabular}{rll}
\hline acat1 & $8 \mathrm{~h}$ & $16 \mathrm{~h}$ \\
\hline diet & 0.31 & 0.10 \\
line & 0.07 & 0.76 \\
diet $\mathrm{x}$ line & 0.02 & 0.22 \\
\hline
\end{tabular}
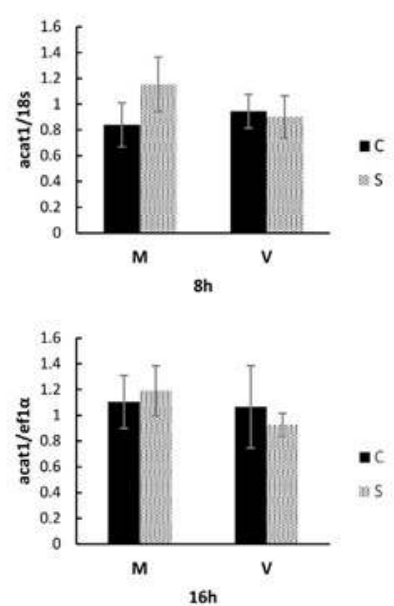
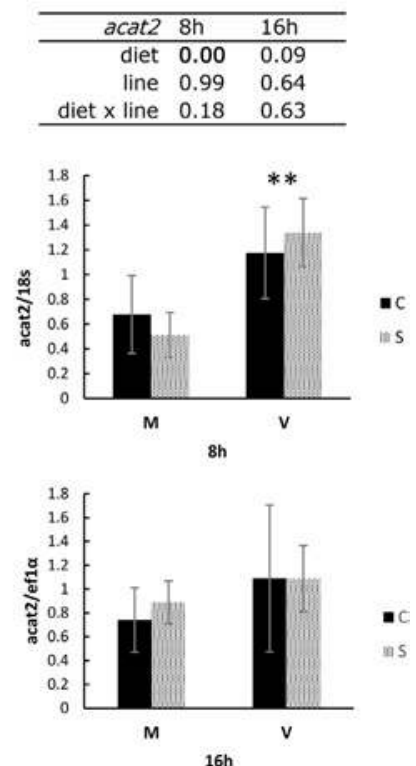

(

\begin{tabular}{rll}
\hline fas & $8 \mathrm{~h}$ & $16 \mathrm{~h}$ \\
\hline diet & 0.00 & 0.01 \\
line & 0.33 & 0.42 \\
diet $\times$ line & 0.56 & 0.87 \\
\hline
\end{tabular}

\begin{tabular}{rll}
\hline srebp-1c & $8 \mathrm{~h}$ & $16 \mathrm{~h}$ \\
\hline diet & 0.04 & 0.00 \\
line & 0.58 & 0.68 \\
diet $\times$ line & 0.56 & 0.68 \\
\hline
\end{tabular}

\begin{tabular}{rll}
\hline gck & $8 \mathrm{~h}$ & $16 \mathrm{~h}$ \\
\hline diet & 0.00 & 0.00 \\
line & 0.04 & 0.91 \\
diet $\times$ line & 0.39 & 0.12 \\
\hline
\end{tabular}
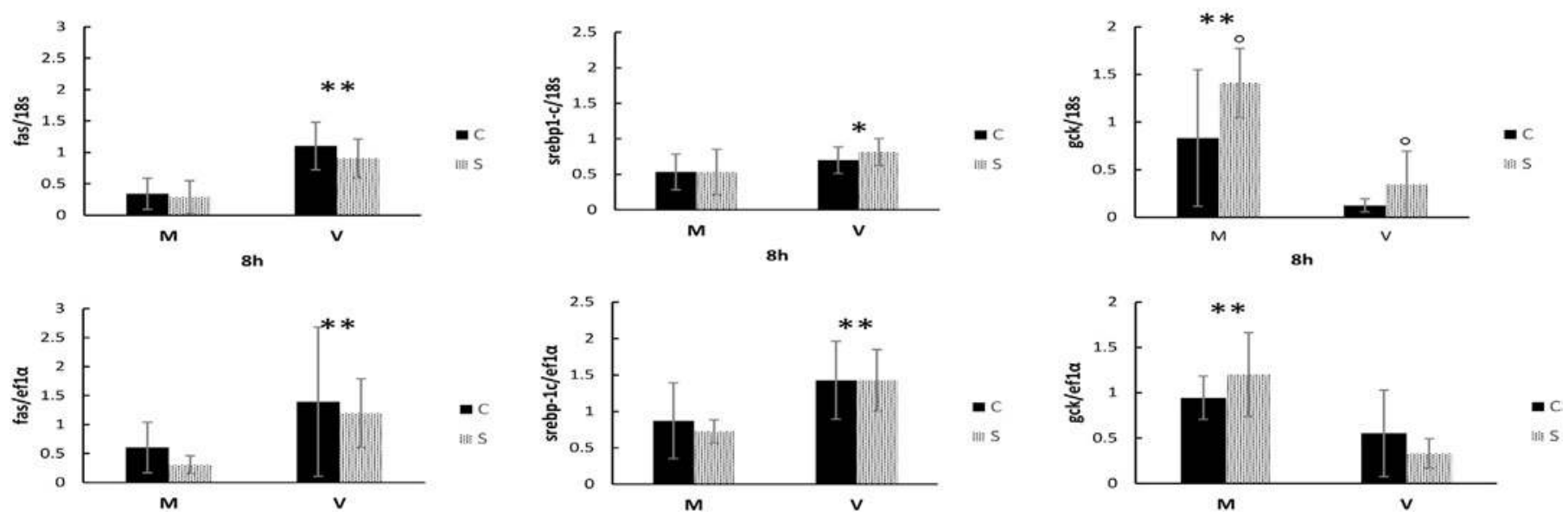

Fig. 2. (continued)

direct target genes and then analyzed the expression of the suggested genes to see if they could be regulated by the corresponding miRNAs.

In contrary to the increased expression of miR-33a in trout fed the $\mathrm{V}$ diet, its putative direct target casp6l2 showed significantly lower expression in trout fed the $\mathrm{V}$ diet regardless of time point, indicating the expression of casp 612 could be post-transcriptionally inhibited by miR33a. The negative correlation between casp6l2 and miR-33a is also consistent with this speculation. CASP6L2 belongs to the caspase family of cysteine proteases associated with immune responses and apoptosis. It is known that the activation of caspases proceeds to the production of pro-inflammatory cytokines and apoptosis (Siegel, 2006). As the immune function is affected in salmonids when marine ingredients are replaced by plant ingredients in aquafeeds (Martin and Król, 2017), the regulation of casp6l2 by diet composition is not surprising.

Among the miR-122 putative target genes analyzed in the present study, only cyp27a7 was found to be affected, with a lower expression in fish fed the $\mathrm{V}$ diet. In the present study, the expression of miR-122 was subjected to an up-regulation linked to selective breeding $8 \mathrm{~h}$ after the last meal and a down-regulation by the plant-based diet $16 \mathrm{~h}$ after the last meal regardless of the fish line. As no significant effect of selective breeding was recorded for cyp27a7 expression, its direct regulation by miR-122 remains questionable. Correspondingly, correlation analysis did not show the negative correlation between miR-122 and cyp27a7, either. The physiological role of CYP27A7 still remains to be determined. However, like the sterol 27-hydroxylase (CYP27A), a member of the same cytochrome family, CYP27A7 may be involved in the cholesterol and bile acid metabolism as well (Dubrac et al., 2005). In this respect, its lower expression in fish fed the $\mathrm{V}$ diet is in agreement with the impact of vegetable diet on cholesterol and bile acid metabolism.

Though the expression of miR-128 was up-regulated in the selected line $8 \mathrm{~h}$ after the last meal, the expression of pde $4 \mathrm{ba}$ and roraa, two 
potential direct targets of miR-128, was not affected by selective breeding. This inconsistency may suggest that miR-128 is not involved in the regulation of these genes at mRNA level. The absence of correlation between miR-128 and pde4ba and roraa also supports this speculation. On the other hand, the expression of these genes did, however, decrease in the trout fed the $\mathrm{V}$ diet. PDE4B belongs to a family of four genes (from PDE4A to D) that act to hydrolyze cAMP and switch off cAMP signaling cascades (Houslay and Adams, 2003). A recent study indicated that an increased hepatic expression of pde $4 b$ could alter cAMP signaling, impair fatty acid oxidation and predispose to liver steatosis (Avila et al., 2016). A current phenotypic trait observed in trout fed the totally plant-based diet showed that the decrease in hepatosomatic index was related to the reduction of lipid content in the liver (Lazzarotto et al., 2015). The reduced expression of pde4ba observed in trout fed the plant-based diet is thus in agreement with the reduced accumulation of fat in the liver, which may be consistent with the role assigned to PDE4B in mammals. RORAA is a member of the retinoid-related orphan receptor (ROR) subfamily. These receptors play critical roles in development, immunity, circadian rhythm, and cellular metabolism (Jetten, 2009). It is reported that impaired expression of ror $\alpha$ in natural $\mathrm{sg} / \mathrm{sg}$ mutant mice leads to reduced plasma cholesterol level by limiting cholesterol efflux. These mice also exhibited reduced

(A)

\begin{tabular}{rll}
\hline rdh14a & $8 \mathrm{~h}$ & $16 \mathrm{~h}$ \\
\hline diet & 0.42 & 0.76 \\
line & 0.69 & 0.77 \\
diet $\times$ line & 0.86 & 0.61 \\
\hline
\end{tabular}
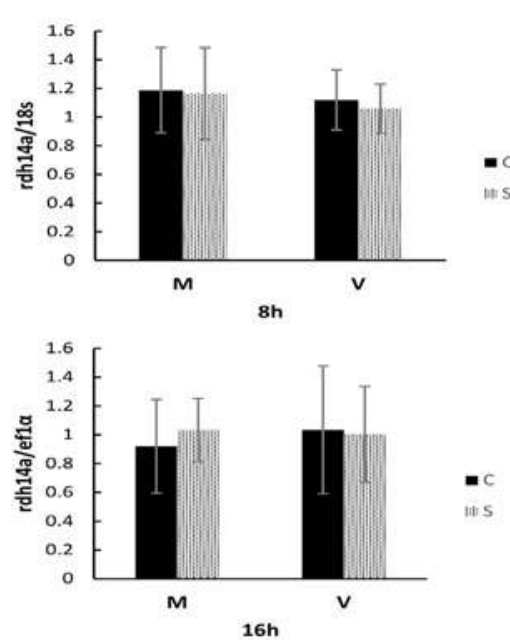

(B)

\begin{tabular}{rll}
\hline mett/5 & $8 \mathrm{~h}$ & $16 \mathrm{~h}$ \\
\hline diet & 0.47 & 0.85 \\
line & 0.64 & 0.86 \\
diet $\mathrm{x}$ line & 0.07 & 0.01 \\
\hline
\end{tabular}
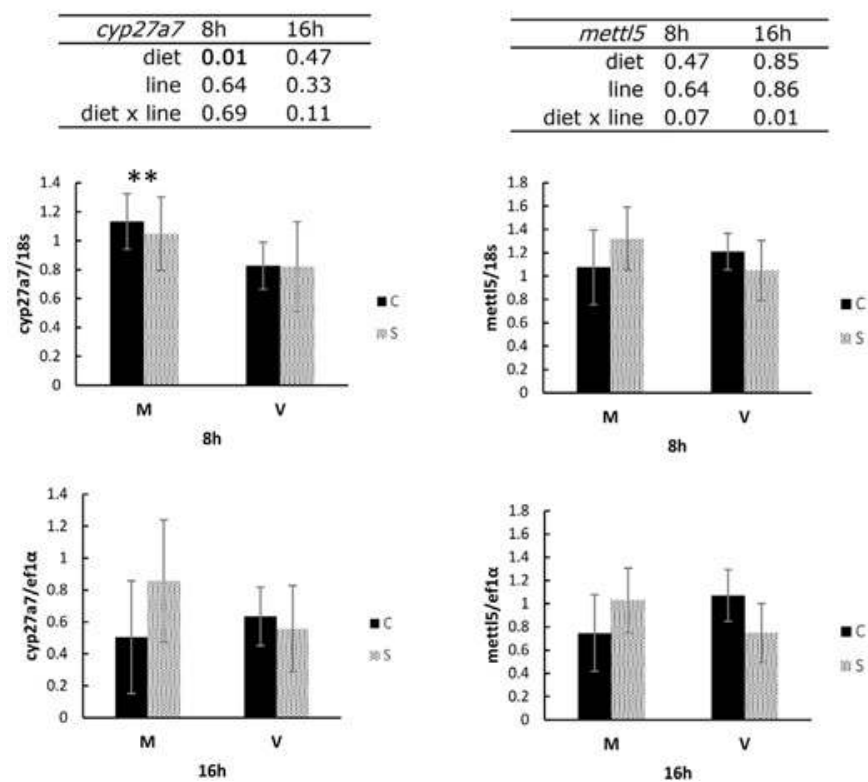

\begin{tabular}{rll}
\hline casp6/2 & $8 \mathrm{~h}$ & $16 \mathrm{~h}$ \\
\hline diet & 0.00 & 0.04 \\
line & $\mathbf{0 . 0 1}$ & 0.36 \\
diet $\times$ line & 0.08 & 0.86 \\
\hline
\end{tabular}
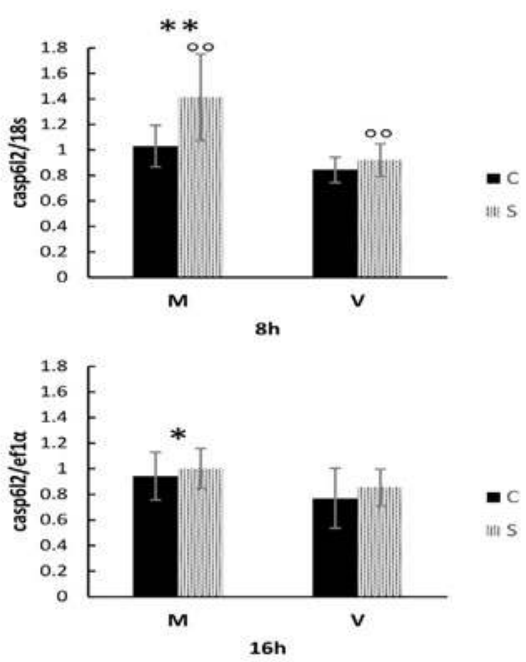

\begin{tabular}{rll}
\hline /cmt2 & $8 \mathrm{~h}$ & $16 \mathrm{~h}$ \\
\hline diet & 0.96 & 0.79 \\
line & 0.75 & 0.22 \\
diet $\times$ line & 0.07 & 0.24 \\
\hline
\end{tabular}
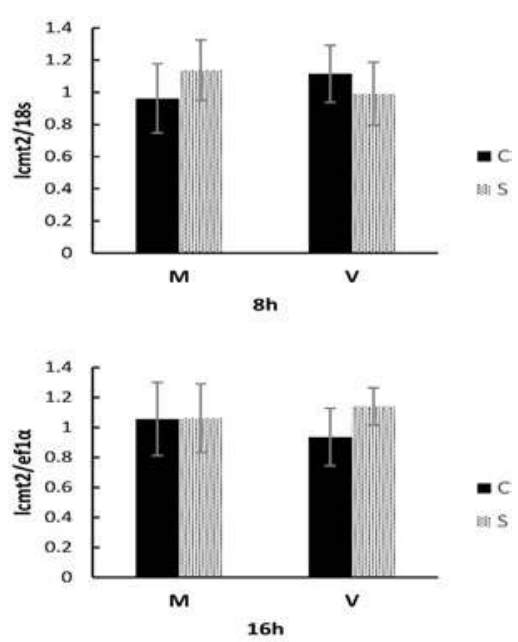
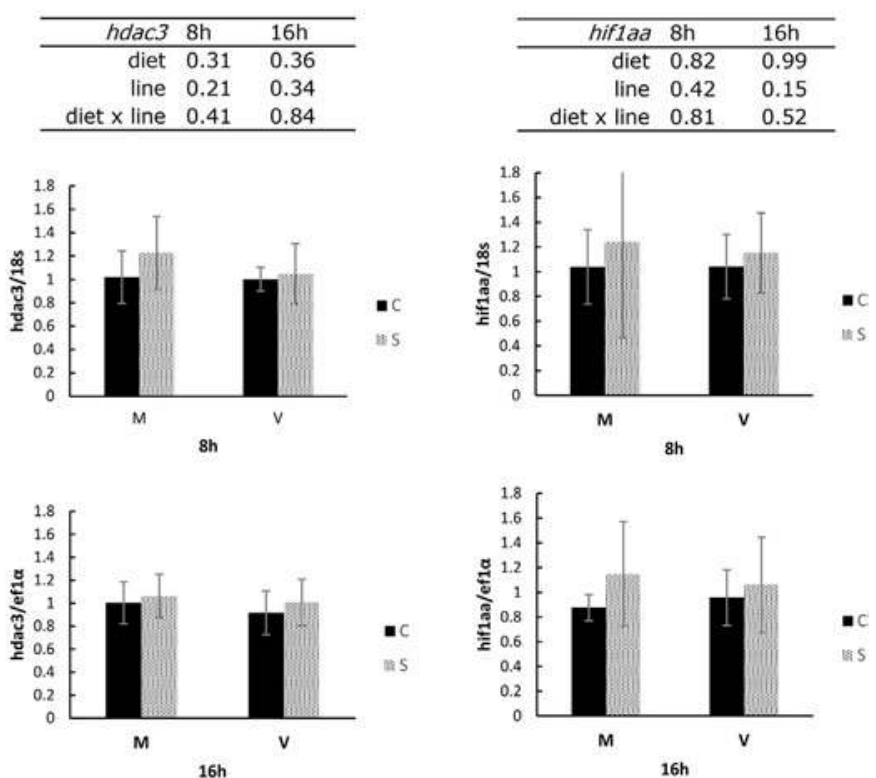

$16 \mathrm{~h}$

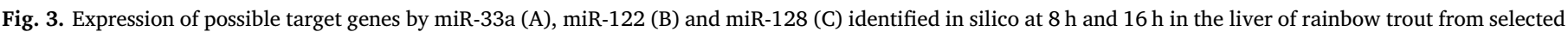

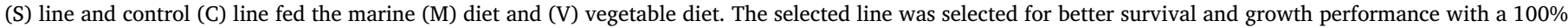

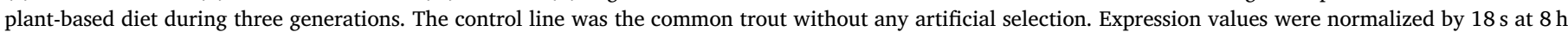

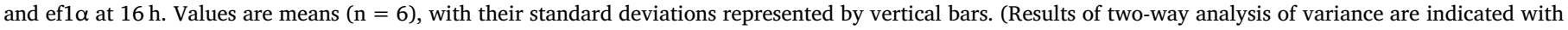
the $P$ value). One star/circle represents a $P$ value $<.05$ for diets/lines, respectively; two stars/circles represent a $P$ value $<.01$ for diets/lines, respectively. 
(C)

\begin{tabular}{rll}
\hline pde $4 b a$ & $8 h$ & $16 h$ \\
\hline diet & 0.02 & 0.00 \\
line & 0.93 & 0.02 \\
diet $\times$ line & 0.95 & 0.63 \\
\hline
\end{tabular}
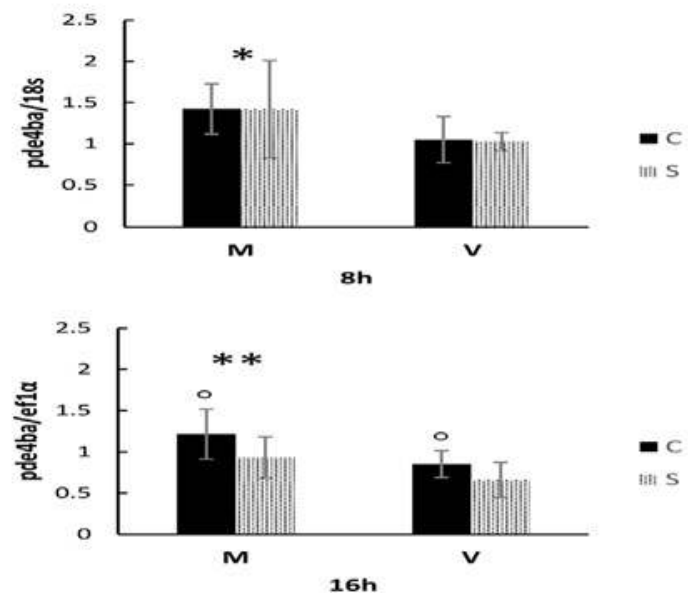

\begin{tabular}{rll}
\hline rorad & $8 h$ & $16 h$ \\
\hline diet & 0.00 & 0.11 \\
line & 0.35 & 0.74 \\
diet $\times$ line & 0.64 & 0.07 \\
\hline
\end{tabular}
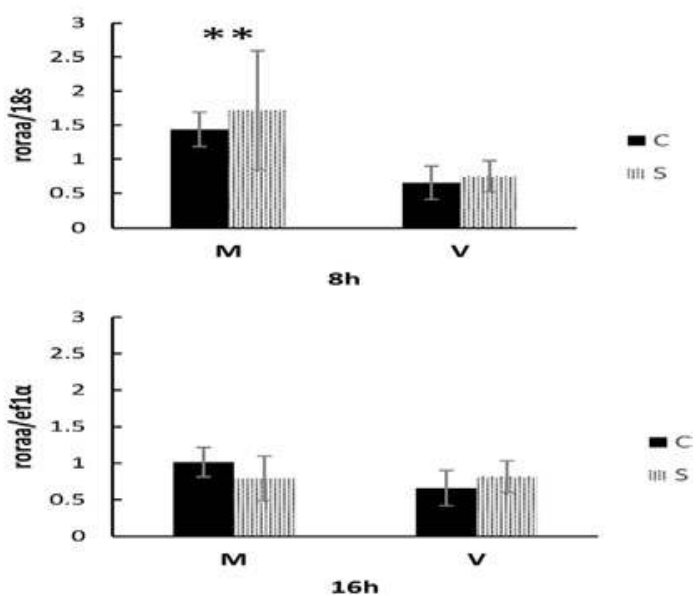

Fig. 3. (continued)

expression of srebp-1c as well as of its target gene, fatty acid synthase (fas) (Lau et al., 2008). In the present study, because the lower expression of roraa but higher expression of abca1, abcg5, srebp-1c and fas in fish fed the plant-based diet was inconsistent with the results in mice study, further investigations are needed to better understand the role of these retinoid-related orphan receptors in trout metabolism.

Among the genes that were chosen as putative targets of miR-33a, -122 and -128 , some of them, including rdh14, lcmt2, mttl5, hdac3 and hif1aa, were neither affected by fish lines nor diets. It has been established that miRNAs regulate gene expression via two main mechanisms depending on the degree of complementarity between miRNA and its target gene. When complementarity is high, mRNA is cleaved and degraded through the RNA-induced silencing complex (RISC). Conversely, low complementarity resulted in translational inhibition of the mRNA target and reduction of the abundance of the encoded protein (Zeng et al., 2003). Thus it is necessary to conduct additional studies at protein level to clearly evaluate the involvement of miR-33a, -122 or -128 in the regulation of these genes.

In conclusion, the present study demonstrated that hepatic expression of miRNAs may be affected by selective breeding of rainbow trout for better adaptation to plant-based diets as well as by total dietary replacement of fishmeal and fish oil by plant ingredients. The miR-33a was found to be greatly induced by plant-based diet whereas miR-122 and miR-128 were affected by selective breeding. This study opens new perspective to evaluate the role of miRNAs in fish nutrition and selective breeding. However, the present study is restricted to the investigation of gene expression at mRNA level instead of protein due to the unavailability of antibodies for Western blot in fish. Even though some relevant regulations were observed between miRNAs and their potential target genes, additional investigations necessitating the development of antibodies are essential to further establish the role of miRNAs in rainbow trout metabolism. Finally, the present study also highlighted some new genes affected by plant-based diet, thus linking this change in dietary composition to, among others, immune response, apoptosis and cAMP signaling pathways. The identification of these new molecular targets in the replacement of marine ingredients by plant products in rainbow trout may aid in opening new fields of investigation to better understand the mechanisms of adaptation to plantbased diet in carnivorous fish.

\section{Acknowledgements}

The authors thank F. Sandres and F. Terrier for manufacturing the experimental diets (INRA, Donzaq, France), L. Labbé and T. Kerneis for fish rearing and A. Herman for technical assistance in the laboratory.

\section{Financial support}

This work was carried out within the framework of the AGREENFISH project (project ANR-13-ADAP-001) funded by the French National Research Agency (ANR). T. Zhu gratefully acknowledges the financial assistance provided by the China Scholarship Council (CSC, File No. 201406330071) for his doctoral fellowship.

\section{Conflict of interest}

None.

\section{Authorship}

SS, GC: formulated research questions and designed the study. EQ, MDN: provided the lines. JM, JB: provided information on direct target gene of miRNA. TZ, EPJ: performed the analysis. TZ, SS, GC: analyzed the data. TZ, SS, GC wrote the paper.

\section{Appendix A. Supplementary data}

Supplementary data to this article can be found online at https:// doi.org/10.1016/j.aquaculture.2018.08.058.

\section{References}

Adlakha, Y.K., Khanna, S., Singh, R., Singh, V.P., Agrawal, A., Saini, N., 2013. Proapoptotic miRNA-128-2 modulates ABCA1, ABCG1 and RXR $\alpha$ expression and cholesterol homeostasis. Cell Death Dis. 4, e780.

AOAC, 2000. Official Methods of Analysis of AOAC International. Gaithersburg, MD USA.

Aryal, B., Singh, A.K., Rotllan, N., Price, N., Fernández-Hernando, C., 2017. MicroRNAs and lipid metabolism. Curr. Opin. Lipidol. 28, 273-280.

Avila, D.V., Barker, D.F., Zhang, J., McClain, C.J., Barve, S., Gobejishvili, L., 2016. Dysregulation of hepatic cAMP levels via altered Pde4b expression plays a critical role in alcohol-induced steatosis. J. Pathol. 240, 96-107. 
Benedito-Palos, L., Navarro, J.C., Sitjà-Bobadilla, A., Bell, J.G., Kaushik, S., PérezSánchez, J., 2008. High levels of vegetable oils in plant protein-rich diets fed to gilthead sea bream (Sparus aurata L.): growth performance, muscle fatty acid profiles and histological alterations of target tissues. Br. J. Nutr. 100, 992-1003.

Bommer, G.T., MacDougald, O.A., 2011. Regulation of lipid homeostasis by the bifunctional SREBF2-miR33a locus. Cell Metab. 13, 241-247.

Callet, T., Médale, F., Larroquet, L., Surget, A., Aguirre, P., Kerneis, T., Labbé, L., Quillet, E., Geurden, I., Skiba-Cassy, S., Dupont-Nivet, M., 2017. Successful selection of rainbow trout (Oncorhynchus mykiss) on their ability to grow with a diet completely devoid of fishmeal and fish oil, and correlated changes in nutritional traits. PLoS One 12, e0186705.

Dubrac, S., Lear, S.R., Ananthanarayanan, M., Balasubramaniyan, N., Bollineni, J., Shefer, S., Hyogo, H., Cohen, D.E., Blanche, P.J., Krauss, R.M., Batta, A.K., Salen, G., Suchy, F.J., Maeda, N., Erickson, S.K., 2005. Role of CYP27A in cholesterol and bile acid metabolism. J. Lipid Res. 46, 76-85.

Esau, C., Davis, S., Murray, S.F., Yu, X.X., Pandey, S.K., Pear, M., Watts, L., Booten, S.L., Graham, M., McKay, R., Subramaniam, A., Propp, S., Lollo, B.A., Freier, S., Bennett, C.F., Bhanot, S., Monia, B.P., 2006. miR-122 regulation of lipid metabolism revealed by in vivo antisense targeting. Cell Metab. 3, 87-98.

FAO, 2016. The State of World Fisheries and Aquaculture: 2016. Contributing to food security and nutrition for all. Rome.

Fox, J., Bouchet-Valat, M., 2016. Rcmdr: R Commander. (R package version 2.3-0).

Geay, F., Ferraresso, S., Zambonino-Infante, J.L., Bargelloni, L., Quentel, C., Vandeputte, M., Kaushik, S., Cahu, C.L., Mazurais, D., 2011. Effects of the total replacement of fish-based diet with plant-based diet on the hepatic transcriptome of two European sea bass (Dicentrarchus labrax) half-sibfamilies showing different growth rates with the plant-based diet. BMC Genomics 12, 522

Gerin, I., Clerbaux, L.A., Haumont, O., Lanthier, N., Das, A.K., Burant, C.F., Leclercq, I.A., MacDougald, O.A., Bommer, G.T., 2010. Expression of miR-33 from an SREBP2 intron inhibits cholesterol export and fatty acid oxidation. J. Biol. Chem. 285, 33652-33661.

Goedeke, L., Fernández-Hernando, C., 2012. Regulation of cholesterol homeostasis. Cell. Mol. Life Sci. 69, 915-930.

Horn, S.S., Sonesson, A.K., Ruyter, B., 2017. Breeding for More Omega-3 in Salmon. Nofima. https://nofima.no/en/nyhet/2017/11/breeding-for-more-omega-3-insalmon/?lang = en.

Houslay, M.D., Adams, D.R., 2003. PDE4 cAMP phosphodiesterases: modular enzymes that orchestrate signalling cross-talk, desensitization and compartmentalization. Biochem. J. 370, 1-18.

Iliopoulos, D., Drosatos, K., Hiyama, Y., Goldberg, I.J., Zannis, V.I., 2010. MicroRNA-370 controls the expression of microRNA-122 and Cpt1alpha and affects lipid metabolism. J. Lipid Res. 51, 1513-1523.

Iwakawa, H., Tomari, Y., 2015. The functions of microRNAs: mRNA decay and translational repression. Trends Cell Biol. 25, 651-665.

Jackson, A., 2012. Fishmeal and fish oil and its role in sustainable aquaculture. Int. Aquafeed 15, 18-21.

Jetten, A.M., 2009. Retinoid-related orphan receptors (RORs): critical roles in development, immunity, circadian rhythm, and cellular metabolism. Nucl. Recept. Signal. 7.

Krützfeldt, J., Rajewsky, N., Braich, R., Rajeev, K.G., Tuschl, T., Manoharan, M., Stoffel, M., 2005. Silencing of microRNAs in vivo with 'antagomirs. Nature 438, 685-689.

Lau, P., Fitzsimmons, R.L., Raichur, S., Wang, S.M., Lechtken, A., Muscat, G.E.O., 2008. The orphan nuclear receptor, $\mathrm{ROR} \alpha$, regulates gene expression that controls lipid metabolism: staggerer (sg/sg) mice are resistant to diet-induced obesity. J. Biol. Chem. 283, 18411-18421.

Lazzarotto, V., Corraze, G., Leprevost, A., Quillet, E., Dupont-Nivet, M., Médale, F., 2015. Three-year breeding cycle of rainbow trout (Oncorhynchus mykiss) fed a plant-based diet, totally free of marine resources: Consequences for reproduction, fatty acid composition and progeny survival. PLoS One 10, 1-17.

Le Boucher, R., Quillet, E., Vandeputte, M., Lecalvez, J.M., Goardon, L., Chatain, B., Médale, F., Dupont-Nivet, M., 2011. Plant-based diet in rainbow trout (Oncorhynchus mykiss Walbaum): are there genotype-diet interactions for main production traits when fish are fed marine vs. plant-based diets from the first meal? Aquaculture 321, 41-48.

Le Boucher, R., Dupont-Nivet, M., Vandeputte, M., Kerneïs, T., Goardon, L., Labbe, L., Chatain, B.B., Bothaire, M.J.J., Larroquet, L., Medale, F., Labbé, L., Chatain, B.B., Bothaire, M.J.J., Larroquet, L., Médale, F., Quillet, E., 2012. Selection for adaptation to dietary shifts: towards sustainable breeding of carnivorous fish. PLoS One 7 , e44898.

Leaver, M.J., Taggart, J.B., Villeneuve, L., Bron, J.E., Guy, D.R., Bishop, S.C., Houston, R.D., Matika, O., Tocher, D.R., 2011. Heritability and mechanisms of $n-3$ long chain polyunsaturated fatty acid deposition in the flesh of Atlantic salmon. Comp. Biochem. Physiol. Part D Genomics Proteomics 6, 62-69.
Li, T., Francl, J.M., Boehme, S., Chiang, J.Y.L., 2013. Regulation of cholesterol and bile acid homeostasis by the cholesterol $7 \alpha$-hydroxylase/steroid response elementbinding protein 2/microRNA-33a axis in mice. Hepatology 58, 1111-1121.

Marquart, T.J., Allen, R.M., Ory, D.S., Baldán, A., 2010. miR-33 links SREBP-2 induction to repression of sterol transporters. Proc. Natl. Acad. Sci. 107, 12228-12232.

Martin, S.A., Król, E., 2017. Nutrigenomics and immune function in fish: new insights from omics technologies. Dev. Comp. Immunol. 75, 86-98.

Mennigen, J.A., Panserat, S., Larquier, M., Plagnes-Juan, E., Medale, F., Seiliez, I., SkibaCassy, S., 2012. Postprandial regulation of hepatic microRNAs predicted to target the insulin pathway in rainbow trout. PLoS One 7, e38604.

Mennigen, J.A., Skiba-Cassy, S., Panserat, S., 2013. Ontogenetic expression of metabolic genes and microRNAs in rainbow trout alevins during the transition from the endogenous to the exogenous feeding period. J. Exp. Biol. 216, 1597-1608.

Mennigen, J.A., Martyniuk, C.J., Seiliez, I., Panserat, S., Skiba-Cassy, S., 2014. Metabolic consequences of microRNA-122 inhibition in rainbow trout, Oncorhynchus mykiss. BMC Genomics 15, 70.

Najafi-Shoushtari, S.H., Kristo, F., Li, Y., Shioda, T., Cohen, D.E., Gerszten, R.E., Näär, A.M., 2010. MicroRNA-33 and the SREBP host genes cooperate to control cholesterol homeostasis. Science 328, 1566-1569.

National Research Council, 2011. Nutrient Requirements of Fish and Shrimp. National academies press, Washington, DC.

Panserat, S., Hortopan, G.A., Plagnes-Juan, E., Kolditz, C., Lansard, M., Skiba-Cassy, S., Esquerré, D., Geurden, I., Médale, F., Kaushik, S., Corraze, G., Esquerre, D., Geurden, I., Medale, F., Kaushik, S., 2009. Differential gene expression after total replacement of dietary fish meal and fish oil by plant products in rainbow trout (Oncorhynchus mykiss) liver. Aquaculture 294, 123-131.

Quinton, C.D., Kause, A., Ruohonen, K., Koskela, J., 2007. Genetic relationships of body composition and feed utilization traits in European whitefish (L.) and implications for selective breeding in fishmeal-and soybean meal-based diet environments. J. Anim. Sci. 85, 3198-3208.

Ramirez, C.M., Da, A., Goedeke, L., Salerno, A.G., Warrier, N., Cirera-Salinas, D., Sua, Y., Ferna, C., 2011. MicroRNA-758 regulates cholesterol efflux through posttranscriptional repression of ATP-binding cassette transporter A1. Arterioscler. Thromb. Vasc. Biol. 31, 2707-2714.

Sakakura, Y., Shimano, H., Sone, H., Takahashi, A., Inoue, K., Toyoshima, H., Suzuki, S., Yamada, N., 2001. Sterol regulatory element-binding proteins induce an entire pathway of cholesterol synthesis. Biochem. Biophys. Res. Commun. 286, 176-183.

Siegel, R.M., 2006. Caspases at the crossroads of immune-cell life and death. Nat. Rev. Immunol. 6, 308-317.

Stadtman, T.C., 1957. [63] Preparation and assay of cholesterol and ergosterol. Methods Enzymol. 3, 392-394.

Tacon, A.G.J., Hasan, M.R., Allan, G., El-Sayed, A.F.M., Jackson, A., Kaushik, S.J., Ng, W.K., Suresh, V., Viana, M.T., 2010. Aquaculture feeds: addressing the long-term sustainability of the sector. In: Proceedings of the Global Conference on Aquaculture, pp. 193-232.

Tay, J.W., James, I., Hughes, Q.W., Tiao, J.Y., Baker, R.I., 2017. Identification of reference miRNAs in plasma useful for the study of oestrogen-responsive miRNAs associated with acquired Protein S deficiency in pregnancy. BMC Res. Notes 10, 312.

Tocher, D.R., Bendiksen, E.Å., Campbell, P.J., Bell, J.G., 2008. The role of phospholipids in nutrition and metabolism of teleost fish. Aquaculture 280, 21-34.

Torstensen, B.E., Espe, M., Sanden, M., Stubhaug, I., Waagbø, R., Hemre, G.-I., Fontanillas, R., Nordgarden, U., Hevrøy, E.M., Olsvik, P., 2008. Novel production of Atlantic salmon (Salmo salar) protein based on combined replacement of fish meal and fish oil with plant meal and vegetable oil blends. Aquaculture 285, 193-200.

Vickers, K.C., Landstreet, S.R., Levin, M.G., Shoucri, B.M., Toth, C.L., Taylor, R.C., Palmisano, B.T., Tabet, F., Cui, H.L., Rye, K.-A., Sethupathy, P., Remaley, A.T., 2014. MicroRNA-223 coordinates cholesterol homeostasis. Proc. Natl. Acad. Sci. 111, 14518-14523.

Wang, L., Jia, X.-J., Jiang, H.-J., Du, Y., Yang, F., Si, S.-Y., Hong, B., 2013. MicroRNAs 185, 96, and 223 repress selective high-density lipoprotein cholesterol uptake through posttranscriptional inhibition. Mol. Cell. Biol. 33, 1956-1964.

Wong, J., Quinn, C.M., Brown, A.J., 2006. SREBP-2 positively regulates transcription of the cholesterol efflux gene, ABCA1, by generating oxysterol ligands for LXR. Biochem. J. 400, 485-491.

Zeng, Y., Yi, R., Cullen, B.R., 2003. MicroRNAs and small interfering RNAs can inhibit mRNA expression by similar mechanisms. Proc. Natl. Acad. Sci. 100, 9779-9784.

Zhao, C., Dahlman-Wright, K., 2010. Liver X receptor in cholesterol metabolism. J. Endocrinol. 204, 233-240.

Zhong, D., Huang, G., Zhang, Y., Zeng, Y., Xu, Z., Zhao, Y., He, X., He, F., 2013. MicroRNA-1 and microRNA-206 suppress LXR $\alpha$-induced lipogenesis in hepatocytes. Cell. Signal. 25, 1429-1437. 